\title{
Sustainable Entrepreneurship: The Role of Perceived Barriers and Risk
}

\author{
Brigitte Hoogendoorn $^{1}$ Peter van der Zwan ${ }^{1,2} \cdot$ Roy Thurik $^{1,3}$
}

Received: 18 July 2016/ Accepted: 13 July 2017/Published online: 8 August 2017

(C) The Author(s) 2017. This article is an open access publication

\begin{abstract}
Entrepreneurs who start a business to serve both self-interests and collective interests by addressing unmet social and environmental needs are usually referred to as sustainable entrepreneurs. Compared with regular entrepreneurs, we argue that sustainable entrepreneurs face specific challenges when establishing their businesses owing to the discrepancy between the creation and appropriation of private value and social value. We hypothesize that when starting a business, sustainable entrepreneurs (1) feel more hampered by perceived barriers, such as the institutional environment and (2) have a different risk attitude and perception than regular entrepreneurs. We use two waves of the Flash Eurobarometer survey on entrepreneurship (2009 and 2012), which contains information on start-up motivations, start-up barriers, and risk perceptions of approximately 3000 (prospective) business owners across 33 countries. We find that sustainable entrepreneurs indeed perceive more institutional barriers in terms of a lack of financial, administrative, and informational support at business start-up than regular entrepreneurs. Further, no significant differences between sustainable and regular entrepreneurs are found in terms of their risk attitudes or perceived financial risks. However, sustainable entrepreneurs are more likely to fear personal
\end{abstract}

Brigitte Hoogendoorn

bhoogendoorn@ese.eur.nl

1 Erasmus School of Economics, Erasmus University Rotterdam, P.O. Box 1738, 3000 DR Rotterdam, The Netherlands

2 Department of Business Studies, Leiden Law School, Leiden University, 2311 ES Leiden, The Netherlands

3 Montpellier Business School, 2300 Avenue des Moulins, 34185 Montpellier-Cedex 4, France failure than regular entrepreneurs, which is explained by their varied and complex stakeholder relations. These insights may serve as an important signal for both governments and private capital providers in enhancing the institutional climate.

Keywords Barriers · Flash Eurobarometer - Institutional environment $\cdot$ Market failures $\cdot$ Risk $\cdot$ Sustainable entrepreneurship

\section{Introduction}

Entrepreneurship and ethical behaviour are closely related. For instance, entrepreneurial qualities such as creativity, novelty, and sensitivity are considered to be similar to the qualities required for moral decision making (Buchholz and Rosenthal 2005). In addition, entrepreneurs face myriad ethical dilemmas when running their ventures (Hannafey 2003), and they increasingly address ethical issues when starting ventures (Quinn 1997). Entrepreneurs who address ethical issues challenge our assumptions about selfinterests and collective interests-or the pursuit of economic gains and the drive to cater to the needs of others. Although the mainstream entrepreneurship literature shows a strong bias towards rational self-interest and the pursuit of private economic gains (Dacin et al. 2010; Van de Ven et al. 2007), the occurrence of other-regarding behaviour has a long tradition in ethics research (Jones et al. 2007; Santos 2012). This paper focuses on so-called sustainable entrepreneurs, i.e. entrepreneurs who start a business to serve self-interests and collective interests by addressing unmet social and environmental needs.

Sustainable entrepreneurs are increasingly acknowledged for addressing current social and environmental 
problems (Hockerts and Wüstenhagen 2010; York and Venkataraman 2010; Zahra et al. 2009). These socially and environmentally conscious individuals fulfil a vital role in society because they offer solutions to complex societal problems that are overlooked, ignored, or unsuccessfully addressed by governments, incumbent businesses, or civil society organizations (Elkington and Hartigan 2008; Kerlin 2009; Nicholls 2006; Nyssens 2006; Zahra et al. 2008). However, the understanding of sustainable entrepreneurs is lacking. For instance, the way in which sustainable entrepreneurs establish their businesses and experience difficulties during the start-up process is far from completely understood.

In comparison with regular entrepreneurs, sustainable entrepreneurs are considered to face specific challenges when establishing their businesses. These challenges may arise because of the discrepancy between the creation of private value and the creation of social value (Dean and McMullen 2007; Groot and Pinkse 2015; Mair and Martí 2006; Pacheco et al. 2010; Santos 2012). The present paper focuses on these presumed challenges and analyses whether sustainable entrepreneurs perceive more barriers and risks than regular entrepreneurs when they set up a business. The present study thus focuses on the creation of new ventures. The creation of new ventures-in addition to their growth and survival-is considered by policymakers to be a key element in economic development (Audretsch and Thurik 2001, 2004).

Regarding barriers, we analyse the degree to which sustainable entrepreneurs feel supported or hampered by the institutional environment when starting their businesses. The dimensions of the institutional environment comprise the perceived lack of financial resources, the perceived degree of complexity of administrative procedures, and the perceived lack of start-up information. Because sustainable entrepreneurs need to challenge existing rules, public policy, norms, and legislation (Dean and McMullen 2007; Hockerts and Wüstenhagen 2010; Meek et al. 2010; Pacheco et al. 2010), we expect them to have more negative perceptions about financial, administrative, and informational support than regular entrepreneurs.

Concerning the risks, we examine the different types of risk that sustainable and regular entrepreneurs may fear. Entrepreneurs are risk takers; however, researchers have argued that different types of entrepreneurs face different types of risks (Block et al. 2015; Shaw and Carter 2007). For example, Shaw and Carter (2007) suggest that social entrepreneurs fear personal risks of a non-financial type, such as the risk of losing local credibility or their network of personal relationships. However, evidence on the differences between sustainable and regular entrepreneurs regarding the types of risk that they fear is lacking. The present paper distinguishes between finance-related risk in terms of possible income loss and bankruptcy and nonfinance-related risk in terms of personal failure. In addition, we compare sustainable and regular entrepreneurs in terms of their willingness to take risks.

In sum, the present study addresses the call to explore the additional complexities of sustainable entrepreneurship (Cohen and Winn 2007). To do so, we focus on the perceived barriers and risks of individuals who have recently made the decision to start a business, i.e. those who are actively taking steps to start a business and those who have been owning-managing a business for fewer than three years. The novelty of the present research is expressed in terms of a few important contributions. First, we add to research focusing exclusively on sustainable entrepreneurial activity by drawing a comparison between sustainable entrepreneurs and regular entrepreneurs in terms of the perceived complexities at business start-up. Differences in perceived barriers and risk corroborate the importance of developing different support programmes for entrepreneurs who are driven to cater to the needs of others compared with entrepreneurs who focus on the pursuit of self-interests. Second, we address heterogeneity in different types of barriers and risks. Our findings provide further evidence that different types of entrepreneurs perceive certain types of risk differently. In particular, the perception of the risk of personal failure seems to be important in the context of sustainable entrepreneurship. Third, we extend current knowledge on sustainable entrepreneurship by using large-scale and internationally comparable data. The use of such data decreases the void in existing research in the area of sustainable entrepreneurship where empirical studies are scarce.

The data that are used for this research were obtained from two waves of the Flash Eurobarometer survey on entrepreneurship (2009 and 2012). This dataset contains information on the start-up motivations, perceived entrepreneurial barriers, and risk attitudes of approximately 3000 individuals across 32 European countries and the USA who are in the process of starting a business or who have just started a business.

The results of this research support the hypothesis that sustainable entrepreneurs have more negative perceptions of financial, administrative, and informational support at business start-up. Moreover, we do not find any noteworthy differences between regular and sustainable entrepreneurs in terms of their risk attitudes and the financial risks that they perceive when running their businesses. Finally, the evidence shows that sustainable entrepreneurs have a greater fear of personal failure than regular entrepreneurs.

The paper is structured as follows. The next section focuses on the background literature and formulates the hypotheses. Next, the data and method are discussed, and the regression results are then presented and discussed. The 
paper ends with a conclusion and avenues for further research.

\section{Background and Hypotheses}

This section starts with a conceptualization of sustainable entrepreneurship and argues why sustainable entrepreneurs face additional challenges when starting a business compared with regular entrepreneurs. Subsequently, hypotheses are formulated in terms of perceived barriers and perceived risk.

\section{Sustainable Entrepreneurship}

Entrepreneurship without the adjective 'sustainable' is already a complex concept. It refers simultaneously to a type of behaviour concentrating on the perception and creation of new economic opportunities (behavioural notion of entrepreneurship) and to the ownership and management of individuals with respect to a business on their own account and risk (occupational notion of entrepreneurship). Entrepreneurial behaviour may concern new business creation, but it can also occur in an existing firm, which is referred to as intrapreneurship or corporate entrepreneurship. Individuals or entrepreneurs may concern the self-employed, the (managerial) business owner in an occupational sense, the independent entrepreneur, and the intrapreneur. Capturing all these aspects, Shane and Venkataraman (2000) define entrepreneurship as “... the scholarly examination of how, by whom and with what effects opportunities to create future goods and services are discovered, evaluated and exploited" (p. 218). By investigating the perceived barriers and risk of business owners, this research can be positioned within the occupational notion of entrepreneurship.

In line with the definition of Shane and Venkataraman (2000) as provided above, the nascent field of sustainable entrepreneurship refers to "the discovery, creation, and exploitation of entrepreneurial opportunities that contribute to sustainability by generating social and environmental gains for others in society" (Groot and Pinkse 2015, p. 634). Sustainable entrepreneurs are motivated to have a positive impact on complex and often intertwined social and ecological problems, such as climate change, nuclear radiation, unequal access to healthcare and education, poverty, and long-term unemployment. More broadly, they are motivated to contribute to sustainable development, which refers to development that "meets the needs of current generations without compromising the ability of future generations to meet their own needs" ((WCED) 1987, p. 43).

Sustainable entrepreneurship is closely related to the fields of social, environmental, and institutional entrepreneurship (Hockerts and Wüstenhagen 2010; Schaltegger and Wagner 2011). To define the concept of sustainable entrepreneurship, we first explore the commonalities and distinctions between social, environmental, and sustainable entrepreneurship. Then, we address the relation between sustainable entrepreneurship and institutional entrepreneurship within the context of this paper.

First, what the fields of social, environmental, ${ }^{1}$ and sustainable entrepreneurship share is the drive of entrepreneurs to create value for others by identifying and seizing upon opportunities arising from problems in society that have been neglected or unsuccessfully addressed by public, private, or civil society organizations (Schaltegger and Wagner 2011; York et al. 2016). In this context, value creation can be understood as an increase in the aggregate utility for society's members owing to entrepreneurial activity (Santos 2012). Regardless of the type of entrepreneurship, value creation at the societal level is a necessary condition for the appropriation of value at the firm level. Santos (2012) nevertheless argues that entrepreneurs differ in the ultimate aim of value creation. In contrast to regular entrepreneurs, the aim of social, environmental, and sustainable entrepreneurs is not limited to and not primarily focussed on the pursuit of value creation for private gains; rather, it includes the pursuit to increase quality of life to the benefit of others (Groot and Pinkse 2015; Santos 2012; Schaltegger and Wagner 2011). Hence, the motivation of social, environmental, and sustainable entrepreneurs deviates from the one-sided pursuit of profit that tends to characterize the regular entrepreneur (Van de Ven et al. 2007; Dacin et al. 2010).

Second, despite this commonality, the fields of social, environmental, and sustainable entrepreneurship differ in a number of aspects, including the relative importance of objectives pursued and the disciplinary roots. ${ }^{2}$ Social entrepreneurs aim to create social benefits by addressing societal problems such as increasing access to healthcare, sanitation, and water in slum areas and revitalizing deprived communities. The creation of social benefits tends to dominate the generation of economic benefits, often in a not-for-profit context (Thompson et al. 2011). According to Thompson et al. (2011), the not-for-profit context can be explained by the fact that the main disciplinary root of social entrepreneurship is the non-profit and public sector. Environmental entrepreneurs aim to protect our natural environment or to recover our ecosystems (York and

\footnotetext{
1 "Environmental entrepreneurship" is also referred to in the literature as "ecopreneurship", "eco-entrepreneurship", or "green entrepreneurship". We consider these concepts to be synonyms. To avoid any confusion, we consistently use "environmental entrepreneurship" throughout this paper.

${ }^{2}$ See, for an overview, Schaltegger and Wagner (2011) and Thompson et al. (2011).
} 
Venkataraman 2010). They do so in a for-profit context that combines environmental and economic value creation (York et al. 2016), with its disciplinary root being environmental economics (Thompson et al. 2011). Sustainable entrepreneurs explicitly focus on a combination of social, environmental, and economic goals (Elkington 1997). Shepherd and Patzelt $(2011$, p. 137) formulate this socalled multiple bottom line as "the preservation of nature, life support, and community in the pursuit of perceived opportunities to bring into existence future products, processes, and services for gain, where gain is broadly construed to include economic and non-economic gains to individuals, the economy, and society". According to Hockerts and Wüstenhagen (2010), sustainable entrepreneurship emerged from the fields of social and environmental entrepreneurship. Hence, sustainable entrepreneurship is sometimes considered to also cover social and environmental entrepreneurship. In the context of this paper, as will be clarified in more detail in "Data" section, we consider entrepreneurs to be sustainable entrepreneurs where the individual —at business start-upis driven by the social and environmental needs of society. Although we distinguish sustainable entrepreneurs from social and environmental entrepreneurs, we draw on the academic literature on these three related fields to arrive at our hypotheses.

Sustainable entrepreneurship and institutional entrepreneurship are also related (Groot and Pinkse 2015; Schaltegger and Wagner 2011; Shepherd and Patzelt 2011). Actors who initiate changes by mobilizing resources directed towards transforming institutional rules, who support or destroy an existing institution, or who establish a new one (DiMaggio 1988) are discussed as institutional entrepreneurs (Battilana et al. 2009; Dacin et al. 2010; DiMaggio 1988). The needs or ambition of sustainable entrepreneurs to change prevailing rules, norms, and market arrangements constitutes a link to institutional entrepreneurship. As we elaborate in the next subsections, sustainable entrepreneurs typically operate in contexts in which markets are characterized by imperfections and failure that serve as a source of opportunities (Cohen and Winn 2007; Dean and McMullen 2007) and that concurrently need to be overcome or changed (Groot and Pinkse 2015; Mair and Martí 2006). Successful sustainable entrepreneurs are able to exert significant influence on their institutional environment and realize social, economic, or political reforms. However, we argue that although they are closely related, not all sustainable entrepreneurs can be considered institutional entrepreneurs in the sense of intentionally initiating and implementing divergent changes. Only entrepreneurs who initiate and actively implement changes in the institutional context as a direct or structural goal of their activities are considered institutional entrepreneurs (Battilana et al. 2009; DiMaggio 1988). In addition, a more recent stream of business-related literature on the sustainability-oriented transformation of society investigates the co-evolutionary processes and contributions of multiple actors in the transformation of entire industries, markets, and economies (Alvord et al. 2004; Hansen and Schaltegger 2013; Hockerts and Wüstenhagen 2010). This stream of literature combines the emergence and development of new entrants or so-called "bioneers" (Schaltegger and Wagner 2011) and the change processes of incumbent firms in becoming more sustainable. In contrast to the more conventional approach of institutional entrepreneurship, the sustainability-oriented transformation perspective has a strong focus on the interplay of actors (Burch et al. 2016; Schaltegger et al. 2016). The focus of the present paper is nevertheless solely on new entrants, who are actors of particular importance because they tend to "kick off sustainability transformation" (Hockerts and Wüstenhagen 2010, p. 488).

The next subsection provides a review of the current understanding of the additional challenges faced by sustainable entrepreneurs compared with regular entrepreneurs. Because sustainable entrepreneurship is an emerging research field and because it is related to the fields of social, environmental, and institutional entrepreneurship, we also draw on these three fields to formulate our hypotheses.

\section{Challenges to Sustainable Entrepreneurs}

By exploiting opportunities arising from neglected social and environmental concerns - and by combining the pursuit of self-interests and collective interests-the objectives of sustainable entrepreneurs are broader in scope and more complex than those of regular entrepreneurs (Groot and Pinkse 2015; Dean and McMullen 2007). The additional complexities are related to the discrepancy between the creation and appropriation of private value and social value (Santos 2012). In response to this discrepancy, we present three arguments regarding why sustainable entrepreneurs experience additional challenges during the start-up process of their business than regular entrepreneurs.

First, sustainable entrepreneurs typically exploit opportunities in markets that are characterized by imperfection and failure (Cohen and Winn 2007; Dean and McMullen 2007; Groot and Pinkse 2015; Mair and Martí 2006; Pacheco et al. 2010). These market failures relate to public goods, externalities, monopoly power, inappropriate government intervention, and imperfect information. Although the pursuit of these opportunities may serve collective and private value creation (Cohen and Winn 2007; Dean and McMullen 2007), operating under circumstances of market failures in the context of environmental and societal challenges poses additional challenges. 
On the one hand, such market failures relate to the characteristics of natural resources and environmental issues (Folke 1999), such as a lack of or unclear property rights, the absence of prices for certain natural resources, and exhaustibility, where use today has consequences for future availability (Cornes and Sandler 1996; Dasgupta 1990). In contrast, for example, well-defined property rights are considered a prerequisite for value appropriation and thus for entrepreneurial activity to occur (Van Stel et al. 2005). Indeed, protecting the natural environment concerns a nonexcludable public good, resulting in low potential for value capture. On the other hand, serving unmet social needs, such as providing sanitation to slum areas and revitalizing deprived communities, clearly limits the capacity in value capture because beneficiaries tend to lack the means to pay for the value creation (DiDomenico et al. 2010; Mair and Martí 2006). In both cases, operating under circumstances of imperfect markets poses additional challenges that need to be overcome by sustainable entrepreneurs at the inception and more established stages of their business.

Second, sustainable entrepreneurs need to initiate institutional change in order to realize changes to existing rules, public policy, norms, and legislation (Dean and McMullen 2007; Hockerts and Wüstenhagen 2010; Meek et al. 2010; Pacheco et al. 2010). The need to change existing institutions in the realm of sustainable entrepreneurship is illustrated by Groot and Pinkse (2015) for clean-energy technologies. Groot and Pinkse (2015) describe the development of electric vehicles under circumstances of insufficient infrastructure and the introduction of renewable energy facing competition from incorrectly priced regular energy sources that are subject to subsidization. Groot and Pinkse (2015) highlight the need for sustainable entrepreneurs to become active in the political arena to create institutional change. Other authors also note that institutional entrepreneurship should become part of sustainable entrepreneurship (Schaltegger and Wagner 2011; Shepherd and Patzelt 2011; Thompson et al. 2011).

Finally, a broad knowledge base is needed among sustainable entrepreneurs because they work under circumstances of market imperfections (see our first point) in an unfavourable institutional context (see our second point) (De Marchi 2012; Marin et al. 2015). Sustainable entrepreneurs must invest their resources in the acquisition of external knowledge, cooperation, and the creation of internal knowledge. Consequently, sustainable entrepreneurs must cope with more varied and more complex stakeholder relations when working with private, public, and civil society sectors (Marin et al. 2015; Nicholls 2006). These findings stress the importance of strong networking skills for sustainable entrepreneurs.

Overall, market imperfections, realizing institutional changes, and a broader knowledge base engender supplementary challenges to the start, growth, and success of sustainable entrepreneurs. We argue that these additional challenges inherent within the exploitation of sustainable opportunities affect entrepreneurs' perceptions of barriers and risks. ${ }^{3}$

\section{Hypothesis Formulation: Perceived Barriers}

The section above describes how the drive for value creation at the societal level over value capture for private gain complicates sustainable entrepreneurs' process of starting and operating their venture. Our second point in our subsection "Challenges to sustainable entrepreneurs" particularly illustrates the need for sustainable entrepreneurs to create institutional change in the presence of barriers. We therefore expect sustainable entrepreneurs to have more negative opinions about the entrepreneurial institutional framework. Specifically, we expect sustainable entrepreneurs to face more problems than regular entrepreneurs in terms of financial and non-financial barriers during start-up. We formulate a separate hypothesis for each type of barrier below.

\section{Perceived Financial Barriers}

Barriers of a financial nature are often mentioned in the related fields of social entrepreneurship (Dorado 2006; Purdue 2001; Sharir and Lerner 2006; Zahra et al. 2009) and environmental entrepreneurship (Groot and Pinkse 2015; Dean and McMullen 2007). Regarding social entrepreneurship, several studies have stressed the difficulties in attracting financial capital (Dorado 2006; Purdue 2001; Sharir and Lerner 2006; Zahra et al. 2009). For example, a large-scale UK survey by the Social Enterprise Coalition shows that access to financing is perceived as a strong barrier to growth among social entrepreneurs (Leahy and Villeneuve-Smith 2009). Several reasons explaining the relative difficulty of obtaining financing that equally relate to the business practice of sustainable entrepreneurs to purposely establish activities in areas with limited value capture potential have been proposed (DiDomenico et al. 2010; Mair and Martí 2006)—an issue akin to our market imperfection argument in our subsection "Challenges to sustainable entrepreneurs". Although this is a strategic choice made by such entrepreneurs, they have to address other stakeholders in establishing and growing their ventures. Such stakeholders are likely to have different

\footnotetext{
3 Although we hypothesize negative perceptions of barriers and risk among sustainable entrepreneurs (see below), we also acknowledge that sustainable entrepreneurs are dedicated and motivated to contribute to sustainability. Hence, sustainable entrepreneurs may be willing to overcome the challenges as indicated above, and hence, their motivation may balance against the negative perceptions.
} 
priorities with respect to value creation and value capture. Business angels, venture capitalists, and other private capital providers will be reluctant to invest if they cannot compensate for their resource commitments. Financial difficulties among sustainable entrepreneurs may also arise because standardized measures for the evaluation of sustainable businesses' performance in terms of social value creation are lacking. This situation complicates the determination of returns to investment and hinders the acquisition of private capital (Nicholls 2009; Zahra et al. 2009).

Although the tension between value creation (for society) and value capture (for private gain) may seem particularly strong in the field of social entrepreneurship, with its disciplinary roots in the non-profit and public sector (Thompson et al. 2011), the same tension holds in the realm of environmental entrepreneurship, albeit for different reasons. With disciplinary roots in environmental economics, scholars have argued that environmental entrepreneurs are hindered in their value-capturing potential because of significant value spillovers arising from the existence of positive externalities (Dean and McMullen 2007; Rangan et al. 2006). Positive externalities create substantial and desirable societal gains. However, such societal gains are unlikely to be appropriated by the venture making the investment. Because these societal gains cannot be fully appropriated, private capital provision will be limited. This problem, referred to as the double externality problem (Rennings 2000), is particularly relevant when the characteristics of natural resources and environmental issues are considered (Folke 1999; Jaffe et al. 2005).

Drawing on the argumentation of the related fields of social and environmental entrepreneurship, we expect that a similar argument holds for sustainable entrepreneurs. In particular, the motivation of sustainable entrepreneurs to contribute to sustainability by generating social and environmental gains for others in society over value capture for private gain may lead to negative perceptions of the availability of financial resources. The following hypothesis is thus formulated:

Hypothesis 1 Compared with regular entrepreneurs, sustainable entrepreneurs are more likely to perceive financial start-up difficulties.

\section{Perceived Non-financial Barriers}

The arguments in our subsection "Challenges to sustainable entrepreneurs" emphasize that sustainable entrepreneurs face different and additional challenges than regular entrepreneurs. The previous subsection hypothesizes that this difference is visible in terms of financial resource mobilization. Additionally, we argue that compared with their regular counterparts, sustainable entrepreneurs are more likely to perceive non-financial barriers related to the institutional context in which they operate. The idea that institutional entrepreneurship is part of sustainable entrepreneurship (Groot and Pinkse 2015; Schaltegger and Wagner 2011; Shepherd and Patzelt 2011) suggests that sustainable entrepreneurs face non-financial barriers. Market failures, such as the monopoly power of incumbents in the electrical utility industry that hinder the provision of alternative energy sources, must be overcome by sustainable entrepreneurs. This is also the case for institutional barriers related to prevailing industry norms and legislation, public policy, and what is considered legitimate conduct (Groot and Pinkse 2015; Hockerts and Wüstenhagen 2010).

Only entrepreneurs who initiate and actively implement changes in the institutional context are considered institutional entrepreneurs (Battilana et al. 2009; DiMaggio 1988). However, not all sustainable entrepreneurs can be considered institutional entrepreneurs in the sense of intentionally initiating and implementing divergent changes. Regardless of whether all sustainable entrepreneurs are considered institutional entrepreneurs, sustainable entrepreneurs face institutional burdens and are likely to perceive more barriers than regular entrepreneurs. Empirical evidence seems to confirm this idea. Sharir and Lerner (2006) and Leeming (2002), for example, observe that social entrepreneurs suffer from a lack of a support infrastructure in Israel and the UK, respectively. According to these authors, social entrepreneurs lack the support of skilled advisors who disseminate information on best practice models and who are able to tailor such models to local conditions. This lack of support infrastructure hinders social entrepreneurs in their development and forces them to "reinvent the wheel" (Leeming 2002). Other empirical studies suggest an additional administrative burden for start-ups addressing sustainability issues. For example, Groot and Pinkse (2015) note that sustainable start-ups are more dependent on government support in terms of subsidies and other incentives, which involve extensive paper work and which lack transparency when they apply for government subsidies. Moreover, additional monitoring and reporting requirements owing to more varied and more complex stakeholder relations (Castka et al. 2004; Rizos et al. 2015) are likely to increase the administrative burden of starting sustainable entrepreneurs. In other words, the administrative procedures and entrepreneurial information are not tailored to sustainable entrepreneurs.

There are two perceptions of infrastructure support regarding the establishment of a business that are used in the present study: an individual's perception of administrative start-up complexities and an individual's perception of insufficient start-up information. If individuals have negative perceptions regarding these two factors, they 
likely feel that they lack environmental support during the process of starting a business. We thus formulate the following two hypotheses:

Hypothesis 2 Compared with regular entrepreneurs, sustainable entrepreneurs are more likely to perceive administrative start-up complexities.

Hypothesis 3 Compared with regular entrepreneurs, sustainable entrepreneurs are more likely to perceive a lack of sufficient information on how to start a business.

\section{Formulation of Hypotheses: Risk}

The role of the entrepreneur is to bring demand and supply for goods and services together, while bearing the risk involved in this process, and to retain any profits that are subsequently derived (Knight 1921). Risk is a central component in any theory on entrepreneurship, where three main concepts can be distinguished: risk attitude, actual risk, and risk perception. One's risk attitude refers to one's risk aversion or risk tolerance and represents one's preferences for one activity over another. Some individuals derive utility from risk-seeking behaviour, whereas others prefer to avoid risk. Most individuals, including entrepreneurs, are relatively risk averse (Parker 2009). All entrepreneurs face some form of risk in terms of profits, which can relate to uncertainty regarding changing consumer tastes, reacting competitors, and changing future prices. Risk perception is the subjective level of risk, and often, it is a biased perception of the actual level of risk. Risk perception differs across individuals: there are optimists and pessimists. Risk attitudes and risk perceptions have a crucial impact on new business creation (Koellinger et al. 2007). Therefore, in this study, we focus on these two risk concepts. We do not claim that the actual level of risk in the context of sustainability is irrelevant. On the contrary, regular firms neglecting sustainability issues in their operations and denying that they are dependent on the environment and society for their existence, continuity, and growth may accept higher levels of actual risk than sustainable entrepreneurs, who consider sustainability. However, we are unable to include the actual level of risk in our analyses owing to data unavailability; hence, we focus on individuals' risk attitude and risk perception.

\section{Risk Attitudes}

The ability to bear uncertainty and risk is required for entrepreneurship, while we know that they play a role in the occupational choice of individuals (Kihlstrom and Laffont 1979; Parker 2009). Differences in an individual's risk attitude influence not only the occupational choice but also the entrepreneur's decision to employ labour and capital and thus the scale of production. Kihlstrom and Laffont (1979) show that within a group of entrepreneurs, differences with regard to risk attitude exist. In a more recent study, Block et al. (2015) observe that hardly any research exists on the risk attitudes of different types of entrepreneurs. They find that an entrepreneur's motivation at venture start-up is associated with their risk attitude. More specifically, individuals starting a venture out of necessity are found to be more risk averse than individuals starting a venture to take advantage of a perceived opportunity (Block et al. 2015).

Entrepreneurs take action in the face of uncertainty, and in this way, the uncertainty is meant to be transformed into an opportunity. Genuine uncertainty is inherent in environmental and societal issues addressed by sustainable entrepreneurs, such as human-induced climate change, where the consequences cannot be predicted because they depend on future actions that are currently unknown (York and Venkataraman 2010). Additionally, it is unclear whether consumers, markets, or governments will reward sustainable strategies (York and Lenox 2014). Hence, in line with our earlier elaboration in our subsection on the additional challenges that sustainable entrepreneurs face compared with regular entrepreneurs, we expect that sustainable entrepreneurs face a higher the level of risk at start-up than their regular counterparts. Being motivated to have a positive impact on complex and intertwined social and environmental challenges requires the willingness to accept risk at start-up and to act despite the existence of true uncertainty. We thus formulate the following hypothesis:

Hypothesis 4 Compared with regular entrepreneurs, sustainable entrepreneurs are more willing to take risks.

\section{Perceived Financial and Non-financial Risk}

In comparison with someone's attitude towards risk, which has received considerable attention in the entrepreneurship literature, the types of risk entrepreneurs that perceive have been researched to a lesser extent. Referring to Liles, Brockhaus (1980, p. 511) suggests that an individual who becomes an entrepreneur risks "financial well-being, career opportunities, family relations, and psychic well-being". Gasse (1982) refers to business, social, psychological, and family risks as risk factors that entrepreneurs encounter. Whether an individual is willing to bear these risks depends on not only individuals' attitude towards risk but also their perception of the different types of risk involved (Weber and Milliman 1997). Where Block et al. (2015) find that an entrepreneur's motivation at venture start-up is associated with her risk attitudes, we assume that an entrepreneur's motivation is also related to her perception of different 
types of risk. We distinguish between risk of a financial type and risk of a non-financial type.

Like entrepreneurs who are primarily driven by value capture and self-interest, sustainable entrepreneurs face the challenge of mobilizing resources to support their start-up. However, sustainable entrepreneurs are likely to face more uncertainties (i.e. additional uncertainties inherent to environmental and societal issues) and the liabilities of newness (i.e. obstacles related to institutional barriers and the requirement of additional and broader knowledge) than their regular counterparts (Van de Ven et al. 2007). Although both regular and sustainable entrepreneurs face challenges in mobilizing resources, we argue that the value-creating mission of sustainable entrepreneurs leads to different risk perceptions.

Sustainable entrepreneurs are motivated by private gains, and they also derive fulfilment from generating social and environmental gains for others in society. In contrast, regular entrepreneurs, being primarily focused on value capture, have to create and maintain a competitive advantage over their rivals in order to avoid having the value that they created spill over to others (Santos 2012). Hence, we expect that the drive to create collective gains over private gains increases the willingness of sustainable entrepreneurs to mobilize financial resources for activities with limited value capture potential. Put differently, sustainable entrepreneurs may perceive the financial risk involved in starting their venture differently because these risks may be offset by other gains.

Additionally, a limited number of empirical studies in the area of social entrepreneurship suggest that social ventures are financed by different sources in comparison with regular ventures. For example, Shaw and Carter (2007) suggest that in the case of social enterprises, personal and family financial resources are rarely used. More recently, Bosma et al. (2016) show that a large fraction of nascent social entrepreneurs in Europe is funded by government programmes, donations, or grants. These observations suggest that sustainable entrepreneurs face a lower risk of losing their own money during or after establishing their business; hence, they have less fear of personal financial risk than regular entrepreneurs. Based on the arguments provided, we formulate the following hypothesis:

Hypothesis 5 Compared with regular entrepreneurs, sustainable entrepreneurs are less likely to fear personal financial risks.

Akin to other types of entrepreneurs, sustainable entrepreneurs are likely to leverage both their formal and informal relational resources in order to achieve their intended entrepreneurial outcomes. As argued earlier, sustainable entrepreneurs are assumed to cope with more varied and more complex stakeholder relations working simultaneously with private, public, and civil society parties. Hence, as also elaborated in our subsection "Challenges to sustainable entrepreneurs", sustainable entrepreneurs require more advanced networking skills and heavier reliance on social capital compared with regular entrepreneurs (Haugh 2007; Marin et al. 2015; Nicholls 2006; Sharir and Lerner 2006). Additionally, sustainable entrepreneurs are likely to use their social ties in a complex and demanding way by sharing their relational resources with other organizations, such as NGOs and lobby parties, to achieve their goals of overcoming and changing institutional barriers (Dacin et al. 2010; Groot and Pinkse 2015). Moreover, ventures in a more established position or environment tend to use more formal relations (Birley 1985). Hence, sustainable entrepreneurs who have to create institutional change rely more heavily on informal social ties. Formal relations are based on contracts and agreements, with clear rights and obligations for each party involved, whereas informal social ties are based on personal relationships grounded in trust.

Overall, we argue that sustainable entrepreneurs are more likely than regular entrepreneurs to put their personal relationships at stake in terms of reputation, probity, and credibility (Leadbeater 1997; Shaw and Carter 2007). Hence, we formulate the following hypothesis:

Hypothesis 6 Compared with regular entrepreneurs, sustainable entrepreneurs are more likely to fear personal failure.

Figure 1 provides a summary of our hypotheses.

\section{Data and Methodology}

\section{Sample}

Our analysis is based on two editions of a survey on entrepreneurial perceptions and involvement that was conducted by TNS Political \& Social on behalf of the European Commission. These so-called Flash Eurobarometer surveys were conducted in 2009 (December) and 2012 (June-August). The European coverage of the survey is substantial: data are available for all 28 Member States of the European Union ${ }^{4}$ complemented with four other European countries (Iceland, Norway, Switzerland, Turkey). Hence, we use data from 32 European countries in total, supplemented with data from the USA. Each national

\footnotetext{
${ }^{4}$ Austria, Belgium, Bulgaria, Croatia, Cyprus, Czech Republic, Denmark, Estonia, Finland, France, Germany, Greece, Hungary, Ireland, Italy, Latvia, Lithuania, Luxembourg, Malta, the Netherlands, Poland, Portugal, Romania, Slovakia, Slovenia, Spain, Sweden, and the UK.
} 
Fig. 1 Overview of the hypotheses and overall findings. Hypotheses represented in bold are supported by our findings; hypotheses represented in italics are not supported

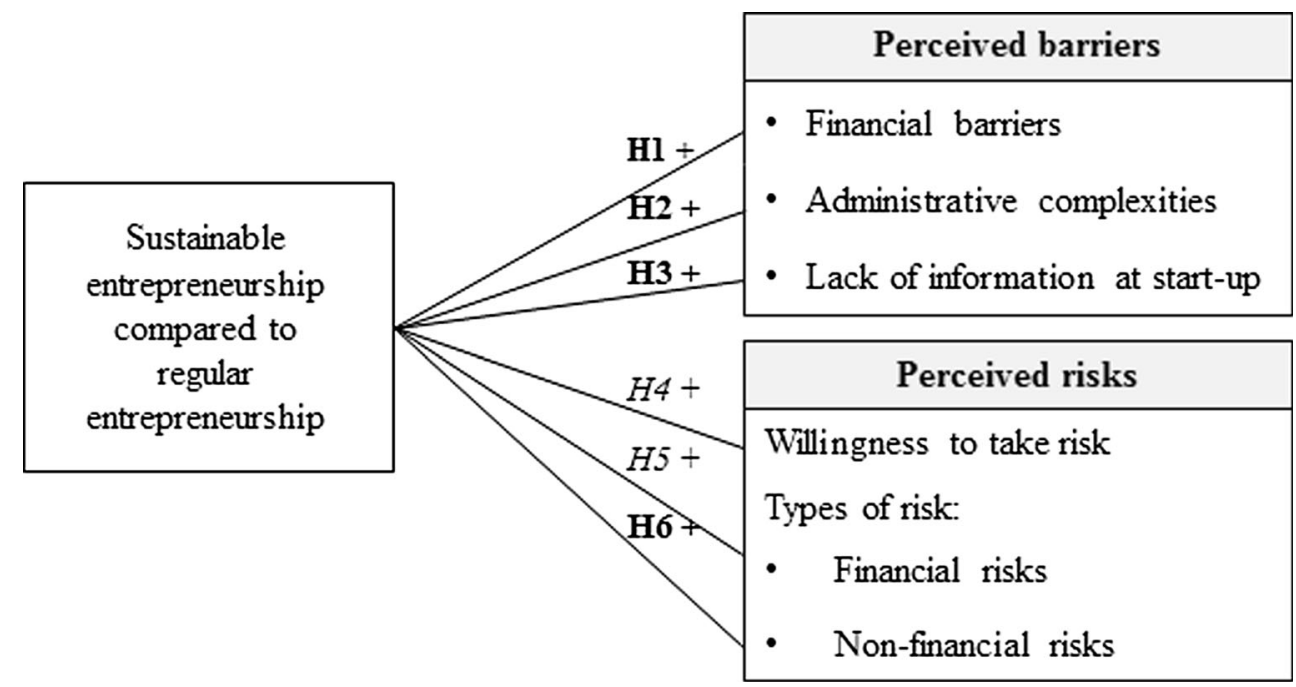

sample is representative of the total population of at least 15 years of age and comprises at least 1000 respondents. The dataset thus consists of 3105 (prospective) business owners, which is the sample used for our estimations.

The survey is representative of the population of each country aged 15 years and over (European Commission 2012). Telephone interviews were conducted, both on fixed lines and mobile phones, using computer-assisted telephone interviewing (CATI). In 2009, there were nine countries in which these telephone interviews $(70 \%)$ were combined with face-to-face interviews (30\%; Bulgaria, Czech Republic, Estonia, Latvia, Lithuania, Hungary, Poland, Romania, Slovakia). In 2013, only telephone interviews were carried out. TNS Political \& Social uses the same random digit dialling process across countries, i.e. telephone numbers from earlier Eurobarometer surveys are used and new numbers are generated by randomly replacing the last two digits. To ensure randomness within a household, respondents who last had a birthday are selected.

\section{Variables}

\section{Sustainable Entrepreneurship}

Our data enable the operationalization of sustainable entrepreneurship in terms of an individual's start-up motivation. Namely, respondents reveal to what extent "addressing an unmet social or ecological need" played a role when they decided to take steps to start a business. The answer categories are "not at all important", "not very important", "fairly important", and "very important". Hence, individuals who answer "not at all important" run businesses that are not sustainable in terms of start-up motivation; we refer to this category as regular entrepreneurship, and it serves as the reference category throughout the analyses. Sustainable entrepreneurs are defined as individuals who indicated that addressing social or ecological needs somehow motivated them to start their venture. The degree of sustainability increases with the three categories "not very important", "fairly important", and "very important". Hence, sustainable entrepreneurship is defined as a categorical variable.

We focus on individuals who have recently made the decision to start a business: those who are actively taking steps to start a business and those who have been owningmanaging a business for fewer than three years. Earlier research also operationalizes entrepreneurship in terms of these so-called nascent entrepreneurs and owner-managers of young businesses (Bacq et al. 2013, 2016; Davidsson 2006; Johnson et al. 2006; Van der Zwan et al. 2012, 2013). We select exactly these individuals for our analysis for a second reason. Our measure of sustainability is related to the start-up motivation, such that the actual start-up must lie in the near future or recent past. For an individual who started a business 20 years ago, for example, it is not as likely that his/her motivation as revealed in the survey matches the actual start-up motivation as for someone who started a business a few months ago.

\section{Perceived Barriers}

Perceived barriers are measured with respondents' perceptions regarding the degree to which they feel supported or hampered by the infrastructure when starting their businesses. Perceived financial barriers are measured as follows. Respondents are asked to assess whether they believe starting a business to be difficult owing to a lack of financial support. The variable takes a value of $1,2,3$, or 4 
in the case of "totally disagree", "tend to disagree", "tend to agree", and "totally agree", respectively.

Perceived non-financial barriers reflect respondents' perceptions about complex administrative procedures when starting a business and the lack of sufficient information on how to start a business. Again, these variables take values of $1,2,3$, or 4 for "totally disagree", "tend to disagree", "tend to agree", and "totally agree", respectively. Hence, high values for the perception variables indicate unfavourable perceptions about the supportiveness of the environment for entrepreneurship.

Although there is no established measure of perceived barriers to start-up, similar items have been used in earlier research (Edelman and Yli-Renko 2010; Grilo and Thurik 2005, 2008), such as when they are related the perceived barriers to entrepreneurial intentions (Shinnar et al. 2012; Kuckertz and Wagner 2010).

\section{Perceived Risk}

Risk attitudes in general are measured with the following statement: "In general, I am willing to take risks". Respondents are asked to judge their willingness to take risks on a four-point scale: "strongly disagree" (value 1), "disagree" (value 2), "agree" (value 3), and "strongly agree" (value 4). Individuals who are willing to take more risk score high on this variable. The measurement of risk attitudes by means of a single question in large-scale surveys is not uncommon, and examples have appeared in earlier research (Bonin et al. 2009; Bönte and Piegeler 2013; Jaeger et al. 2010). The usefulness of a general selfassessment of risk by respondents is demonstrated by Dohmen et al. (2011, p.524), who conclude that “(...) responses to the general risk question are a reliable predictor of actual risky behaviour, even controlling for a large number of observables".

Furthermore, we focus on different types of risks that entrepreneurs take during the process of establishing and running a venture. Specifically, we distinguish between two perceived financial risks (possibility of income loss and bankruptcy) and one perceived non-financial risk (personal failure). These three variables are binary: if a risk factor is deemed important by the respondent, then a value of 1 is assigned for this particular risk factor and a value of 0 is assigned otherwise.

Financial and non-financial risks have been considered earlier by means of single items. For instance, Ray (1994) compares entrepreneurs and non-entrepreneurs regarding their assessment of several risks should a business fail. According to Ray (1994), entrepreneurs are more pessimistic than non-entrepreneurs about losing their money (in the case of venture failure) and are more afraid of losing their self-image and self-respect than non-entrepreneurs.
Entrepreneurs are also more likely to associate business failure with losing money than non-entrepreneurs (McGrath and MacMillan 1992). An assessment of perceived risks within the group of entrepreneurs has not been undertaken in earlier research.

Our risk factors are closely related to the concept of fear that may play a role in the establishment of a business. Here, we include fear about one's own reputation and personal failure, on the one hand, and fear about the financial repercussions, on the other. The concept of fear of failure has been measured with a single item in previous research (Arenius and Minniti 2005; Koellinger et al. 2013).

\section{Control Variables}

Sociodemographic variables We control for gender ( 1 = male; 0 = female), age, and educational attainment. Education refers to the age at which an individual finished his/her fulltime education, and it is a continuous variable with values between 15 and 25 . Household income is also added as a control variable. In our questionnaire, this is a subjective question where respondents indicate which of the following descriptions applies: "find it very hard to manage on the present income", "find it difficult to manage on the present income", "get by on the present income", and "live comfortably on the present income" (added as a categorical variable).

Stage in the entrepreneurial process We distinguish between nascent entrepreneurs, i.e. those actively taking steps to start a business (value 0) and owner-managers of recently started businesses (value 1).

Country and year We also include country dummies to control for country-specific influences. Compared with those in many studies in this research area focused on a single country, our sample is able to provide more generalized results. Finally, a year dummy variable is included (1 for 2012; 0 for 2009) to control for all differences between the two data collection rounds.

We justify our set of control variables from the viewpoint of the perceived barriers and perceived risk factors, which are used as dependent variables in our regressions (see below). In terms of the perceived barriers, previous studies show that women have more negative perceptions than men towards the supportiveness of the entrepreneurial environment (Shinnar et al. 2012; Verheul et al. 2012). We also control for age, education, and household income. A negative relationship exists between the perceived lack of entrepreneurial support and entrepreneurial intentions (Shinnar et al. 2012), and intentions have been shown to depend on age, education, and income in previous literature (Lee et al. 2011). In addition, entrepreneurial perceptions 
seem to be different across cultures (Shinnar et al. 2012), which justifies the inclusion of country dummies.

Regarding the perceived risk factors, we first draw from studies that investigate individual differences in risk attitudes by using self-reports. Dohmen et al. (2011) find important roles for an individual's gender, age, and educational attainment in explaining differences in risk attitudes, and they highlight household income as a relevant driver. Although they use a different measure, Hartog et al. (2002) also find higher risk-taking propensities for men, more educated individuals, and individuals with higher incomes. Further, studies focusing on fear of failure find that fear is lower among men and that fear decreases with age, education, and household income (Koellinger et al. 2013). It may also be that risk attitudes differ depending on the individual's stage in entrepreneurship. While many studies conclude that risk propensities are higher among entrepreneurs than non-entrepreneurs, Xu and Ruef (2004) find lower risk propensities among nascent entrepreneurs than among non-entrepreneurs. This finding highlights the potentially important role of the stage of entrepreneurship. Overall, we include country dummies in our analyses because risk-tasking propensities significantly vary across cultures (Thomas and Mueller 2000).

Table 1 provides an overview of the variables. ${ }^{5}$ Table 2 shows a correlation matrix. ${ }^{6}$

\section{Methodology}

Our empirical exercise aims to determine how sustainability is related to the perceived barriers and risk. Hypotheses 1, 2, and 3 are tested by using ordered logit regressions where perceived (non-)financial barriers are the dependent variables. Hypothesis 4 is also tested by using an ordered logit regression where the willingness to take risks is the dependent variable. For Hypotheses 5 and 6, binary logit regressions are used with the binary (non-)financial risk variables as the dependent variables.

As indicated previously, sustainability is a categorical independent variable in each of the above regressions, where "not at all important" is used as the reference category.

Average marginal effects are calculated to enhance interpretation. For the ordered logit models, we show the average marginal effects for the highest category of the dependent variable only ("totally agree" for the perceived

\footnotetext{
5 Weights, provided by TNS Political \& Social, are applied based on sociodemographic aspects, including gender, age, and region.

${ }^{6}$ For the sake of brevity, we treat all variables as continuous variables in the correlation table, and hence, we calculate Pearson correlation coefficients for each pair of variables.
}

barriers and "strongly agree" for the willingness to take risks). The marginal effects are based on heteroskedasticrobust standard errors of the original coefficients by clustering them over countries.

\section{Results}

\section{Perceived Barriers}

Table 3 displays the results of three ordered logit regressions, where each perceived barrier acts as a dependent variable. Note that the sustainability variable is treated as a categorical variable. Namely, the four categories of the variable are added as separate dummy variables, where "not at all important"- the lowest category-serves as the reference category.

Hypothesis 1 is tested in column 1 of Table 3, where the perceived lack of financial support is the dependent variable. The marginal effects belonging to the highest category of the dependent variable are shown for the sake of brevity. The marginal effects for the other three categories of the dependent variable are given in Table 5 in "Appendix". The results in column 1 of Table 3 reveal that sustainable entrepreneurs are significantly more likely than regular entrepreneurs to perceive financial start-up barriers. In particular, the marginal effect of "very important"associated with the highest degree of sustainability-is significantly different from zero $(p$ value $<0.05)$. The probability of perceiving financial barriers (in terms of belonging to the highest category) is 5.1 percentage points higher for entrepreneurs with the highest degree of sustainability than for regular entrepreneurs. The "baseline" probability of belonging to the highest category of the dependent variable is also shown in Table 3 (predicted probabilities in the first row).

The results in column 2 of Table 3 provide a test for Hypothesis 2. Based on the marginal effects, we find support for Hypothesis 2. Namely, sustainable entrepreneurs are significantly more likely to perceive administrative complexities than regular entrepreneurs ( $p$ values $<0.01$ for "fairly important" and "very important"). The probability of perceiving administrative complexities is 11.1 percentage points higher for sustainable entrepreneurs ("very important") than for regular entrepreneurs. Support is also found for Hypothesis 3 in column 3 of Table 3. Specifically, sustainable entrepreneurs are significantly more likely to perceive a lack of sufficient information regarding how to start a business than regular entrepreneurs ( $p$ values $<0.05$ for "fairly important" and "very important"). The associated increase in the probability of perceiving insufficient start-up information is 5.4 percentage points. 
Table 1 Overview of variables

\begin{tabular}{|c|c|c|c|c|c|}
\hline & Obs. & Mean & S.D. & Min. & Max. \\
\hline \multicolumn{6}{|l|}{ Sustainability } \\
\hline Not at all important (reference category in regressions) & 3105 & 0.11 & 0.32 & 0 & 1 \\
\hline Not very important $(1 / 0)$ & 3105 & 0.20 & 0.40 & 0 & 1 \\
\hline Fairly important $(1 / 0)$ & 3105 & 0.37 & 0.48 & 0 & 1 \\
\hline Very important $(1 / 0)$ & 3105 & 0.31 & 0.46 & 0 & 1 \\
\hline \multicolumn{6}{|l|}{ Dependent variables } \\
\hline Perceived financial barrier & 3105 & 3.17 & 0.87 & 1 & 4 \\
\hline Perceived non-financial barrier: administrative complexities & 3105 & 2.90 & 1.00 & 1 & 4 \\
\hline Perceived non-financial barrier: lack of start-up info & 3105 & 2.49 & 1.06 & 1 & 4 \\
\hline Willingness to take risks & 1234 & 3.11 & 0.75 & 1 & 4 \\
\hline Perceived financial risk: income $(1 / 0)$ & 3105 & 0.45 & 0.50 & 0 & 1 \\
\hline Perceived financial risk: bankruptcy $(1 / 0)$ & 3105 & 0.41 & 0.49 & 0 & 1 \\
\hline Perceived non-financial risk: personal failure $(1 / 0)$ & 3105 & 0.21 & 0.41 & 0 & 1 \\
\hline \multicolumn{6}{|l|}{ Control variables } \\
\hline Male $(1=$ male; $0=$ female $)$ & 3105 & 0.63 & 0.48 & 0 & 1 \\
\hline Age & 3105 & 36.89 & 12.99 & 15 & 86 \\
\hline Education & 3105 & 20.57 & 3.23 & 15 & 25 \\
\hline \multicolumn{6}{|l|}{ Household $(\mathrm{HH})$ income } \\
\hline Find it very hard on the present income (reference category in regressions) & 3105 & 0.08 & 0.27 & 0 & 1 \\
\hline Find it difficult on the present income $(1 / 0)$ & 3105 & 0.17 & 0.38 & 0 & 1 \\
\hline Get by on the present income $(1 / 0)$ & 3105 & 0.46 & 0.50 & 0 & 1 \\
\hline Live comfortably on the present income $(1 / 0)$ & 3105 & 0.29 & 0.45 & 0 & 1 \\
\hline Young (1) versus nascent $(0)$ & 3105 & 0.43 & 0.49 & 0 & 1 \\
\hline 2012 (1) versus $2009(0)$ & 3105 & 0.65 & 0.48 & 0 & 1 \\
\hline
\end{tabular}

S.D. standard deviation (transformation of the mean in case of $1 / 0$ variables); Min. minimum value; Max. maximum value. Country dummies are included in the regressions as well

Survey questions on perceived barriers and perceived risk

It is difficult to start one's own business due to a lack of available financial support (totally disagree-value 1 to totally agree-value 4 )

It is difficult to start one's own business due to the complex administrative procedures (totally disagree-value 1 to totally agree-value 4)

It is difficult to obtain sufficient information on how to start a business (totally disagree-value 1 to totally agree-value 4)

In general, I am willing to take risks (available for 2009 only) (strongly disagree-value 1 to strongly agree-value 4)

If you were to set up a business today, which are the two risks you would be most afraid of? Irregular/not-guaranteed income; the possibility of going bankrupt; the possibility of suffering a personal failure. If a risk factor is deemed important by the respondent, a value of 1 is assigned; 0 otherwise

\section{Perceived Risk}

Table 4 focuses on perceived risk. Hypothesis 4 is tested in column 1 of Table 4 with an ordered logit regression and willingness to take risks as the dependent variable. Again, the marginal effects corresponding to the highest category of willingness to take risks are displayed (the marginal effects for the other categories are given in Table 6 in "Appendix"). Note that higher values for this variable indicate a higher willingness to take risks. Based on the results in column 1 of Table 4 , we do not find support for Hypothesis 4 . The marginal effects corresponding to the categories of sustainable entrepreneurship are non-significant ( $p$ values $>0.10$ ).

Hypothesis 5 is tested in columns 2 and 3 of Table 4, where the binary dependent variables reflect one's fear of income loss and one's fear of bankruptcy, respectively. Note that binary logit regressions have been performed here. Hypothesis 5 is not supported, given the non-significance ( $p$ values $>0.10$ ) of the marginal effects of the categories of the sustainability variable.

Finally, Hypothesis 6 is tested in column 4 of Table 4, where personal failure is the dependent variable. We find support for Hypothesis 6. Namely, sustainable 
Table 2 Correlation matrix

\begin{tabular}{|c|c|c|c|c|c|c|c|c|c|c|c|c|c|}
\hline & 1. & 2. & 3. & 4. & 5. & 6. & 7. & 8. & 9. & 10. & 11. & 12. & 13. \\
\hline 1. Sustainability & 1.00 & & & & & & & & & & & & \\
\hline $\begin{array}{l}\text { 2. Financial } \\
\text { barrier }\end{array}$ & $0.11 *$ & 1.00 & & & & & & & & & & & \\
\hline $\begin{array}{l}\text { 3. Administr. } \\
\text { compl. }\end{array}$ & $0.12 *$ & $0.32 *$ & 1.00 & & & & & & & & & & \\
\hline $\begin{array}{l}\text { 4. Lack start-up } \\
\text { info }\end{array}$ & $0.11 *$ & $0.25 *$ & $0.39 *$ & 1.00 & & & & & & & & & \\
\hline $\begin{array}{l}\text { 5. Willingness } \\
\text { take risks }\end{array}$ & 0.04 & -0.00 & -0.01 & 0.01 & 1.00 & & & & & & & & \\
\hline 6. Risk income & -0.02 & -0.01 & -0.03 & 0.01 & 0.01 & 1.00 & & & & & & & \\
\hline $\begin{array}{l}\text { 7. Risk } \\
\text { bankruptcy }\end{array}$ & 0.02 & $0.08 *$ & $0.06 *$ & $0.06^{*}$ & -0.02 & $-0.31^{*}$ & 1.00 & & & & & & \\
\hline 8. Personal failure & $0.06^{*}$ & -0.02 & 0.03 & 0.01 & 0.02 & $-0.21 *$ & $-0.11 *$ & 1.00 & & & & & \\
\hline 9. Male & $-0.06^{*}$ & -0.02 & 0.00 & -0.03 & $0.11 *$ & $-0.05^{*}$ & $0.05 *$ & $-0.04 *$ & 1.00 & & & & \\
\hline 10. Age & $-0.08 *$ & $-0.03 *$ & 0.02 & $-0.05 *$ & $-0.10 *$ & $-0.05^{*}$ & $-0.09 *$ & -0.02 & $-0.07 *$ & 1.00 & & & \\
\hline 11. Education & $-0.06^{*}$ & $-0.08^{*}$ & $-0.08 *$ & $-0.10 *$ & $0.07 *$ & $0.05 *$ & $-0.07 *$ & 0.01 & -0.02 & $0.11 *$ & 1.00 & & \\
\hline 12. $\mathrm{HH}$ income & $-0.10^{*}$ & $-0.19^{*}$ & $-0.11 *$ & $-0.12 *$ & $0.05 *$ & -0.02 & -0.03 & $0.04 *$ & $0.05 *$ & 0.00 & $0.13 *$ & 1.00 & \\
\hline $\begin{array}{l}\text { 13. Young versus } \\
\text { nascent }\end{array}$ & $-0.14 *$ & $-0.04 *$ & $-0.07 *$ & -0.03 & -0.05 & $0.03 *$ & 0.00 & $-0.09 *$ & 0.02 & $0.17 *$ & $0.04 *$ & $0.11 *$ & 1.00 \\
\hline $\begin{array}{l}\text { 14. } 2012 \text { versus } \\
2009\end{array}$ & $0.04 *$ & $0.06 *$ & 0.01 & $-0.04 *$ & N.a. & $-0.08^{*}$ & $-0.05^{*}$ & $-0.04 *$ & $0.04 *$ & $-0.12 *$ & 0.00 & 0.01 & $-0.04 *$ \\
\hline
\end{tabular}

Pearson correlations have been calculated for all variables

$* p$ value $<0.10$

Information for willingness to take risks available for 2009 only

entrepreneurs are significantly more likely than regular entrepreneurs to fear personal failure ( $p$ value $<0.10$ for "very important"). The probability of fearing personal failure is 4.8 percentage points higher for entrepreneurs with the highest degree of sustainability than for regular entrepreneurs.

An overview of our hypotheses and the overall findings is provided in Fig. 1.

\section{Additional Analyses}

A first extension to our main analysis is presented in Tables 5 and 6 in "Appendix". These tables show the marginal effects for perceived barriers and willingness to take risks, respectively, and focus on the lowest three categories of the dependent variables rather than the highest category. These results do not lead to substantially different conclusions.

The second extension refers to the results in Tables 7 (similar to Table 3) and 8 (similar to Table 4) in "Appendix". They show the results for the sustainability variable when "fairly important" is taken as the reference category. Rather than comparing sustainable entrepreneurs with regular entrepreneurs (as in our main analysis), this additional analysis assesses whether there are also differences among sustainable entrepreneurs in how they perceive barriers and risks. We verify such differences within the group of sustainable entrepreneurs for the perceived financial and non-financial barriers (Table 7): a higher degree of sustainability is associated with more unfavourable perceptions of financial and non-financial support when entrepreneurs establish businesses. Furthermore, Table 8 reveals that more sustainable entrepreneurs are significantly more willing to take risks (column 1) and are significantly more likely to fear personal failure (column 4) than less sustainable entrepreneurs. Hence, we find differences not only between regular and sustainable entrepreneurs (see Tables 3 and 4) but also within the pool of sustainable entrepreneurs, regarding their perceptions of barriers and risks.

We assess the robustness of our results by performing three alternative analyses (the results of these analyses are not tabulated but discussed below). First, we include a continuous version of our sustainability variable in our regressions. The relevant marginal effects (not shown; again for the highest category) are 0.021 (standard error: 
Table 3 Ordered logit regressions with perceived barriers as the dependent variable: average marginal effects are shown

\begin{tabular}{|c|c|c|c|}
\hline & $\begin{array}{l}(1) \\
\text { Perceived financial } \\
\text { barrier (H1) }\end{array}$ & $\begin{array}{l}\text { (2) } \\
\text { Perceived non-financial barrier: } \\
\text { administrative complexities }(\mathrm{H} 2)\end{array}$ & $\begin{array}{l}\text { (3) } \\
\text { Perceived non-financial barrier: } \\
\text { lack of start-up info (H3) }\end{array}$ \\
\hline Predicted probability & 0.439 & 0.356 & 0.225 \\
\hline Sustainability (not very important) & $\begin{array}{l}-0.017 \\
(0.025)\end{array}$ & $\begin{array}{l}0.036 \\
(0.031)\end{array}$ & $\begin{array}{l}0.005 \\
(0.017)\end{array}$ \\
\hline Sustainability (fairly important) & $\begin{array}{l}0.001 \\
(0.023)\end{array}$ & $\begin{array}{l}0.073 * * * \\
(0.024)\end{array}$ & $\begin{array}{l}0.041 * * \\
(0.019)\end{array}$ \\
\hline Sustainability (very important) & $\begin{array}{l}0.051 * * \\
(0.023)\end{array}$ & $\begin{array}{l}0.111 * * * \\
(0.028)\end{array}$ & $\begin{array}{l}0.054 * * * \\
(0.021)\end{array}$ \\
\hline \multicolumn{4}{|l|}{ Control variables } \\
\hline Male & $\begin{array}{l}-0.002 \\
(0.016)\end{array}$ & $\begin{array}{l}0.010 \\
(0.017)\end{array}$ & $\begin{array}{l}-0.015 \\
(0.010)\end{array}$ \\
\hline Age & $\begin{array}{l}0.000 \\
(0.001)\end{array}$ & $\begin{array}{l}0.002 * * * \\
(0.000)\end{array}$ & $\begin{array}{l}-0.000 \\
(0.000)\end{array}$ \\
\hline Education & $\begin{array}{l}-0.005^{*} \\
(0.002)\end{array}$ & $\begin{array}{l}-0.006^{* * *} \\
(0.002)\end{array}$ & $\begin{array}{l}-0.005^{* * *} \\
(0.002)\end{array}$ \\
\hline $\mathrm{HH}$ income (find it difficult) & $\begin{array}{l}0.024 \\
(0.044)\end{array}$ & $\begin{array}{l}-0.041 \\
(0.035)\end{array}$ & $\begin{array}{l}-0.006 \\
(0.037)\end{array}$ \\
\hline HH income (get by) & $\begin{array}{l}-0.089 * * \\
(0.037)\end{array}$ & $\begin{array}{l}-0.087 * * \\
(0.037)\end{array}$ & $\begin{array}{l}-0.024 \\
(0.033)\end{array}$ \\
\hline HH income (live comfortably) & $\begin{array}{l}-0.177 * * * \\
(0.041)\end{array}$ & $\begin{array}{l}-0.099 * * * \\
(0.038)\end{array}$ & $\begin{array}{l}-0.045 \\
(0.034)\end{array}$ \\
\hline Young versus nascent & $\begin{array}{l}-0.002 \\
(0.013)\end{array}$ & $\begin{array}{l}-0.044 * * * \\
(0.015)\end{array}$ & $\begin{array}{l}-0.008 \\
(0.010)\end{array}$ \\
\hline 2012 versus 2009 & $\begin{array}{l}0.080 * * \\
(0.040)\end{array}$ & $\begin{array}{l}0.029 * \\
(0.017)\end{array}$ & $\begin{array}{l}-0.010 \\
(0.012)\end{array}$ \\
\hline Observations & 3105 & 3105 & 3105 \\
\hline
\end{tabular}

Standard errors (clustered on country) in parentheses. Country dummies are included, but corresponding marginal effects not shown here. Marginal effects are shown for the highest category of the dependent variables (totally agree-value 4). Marginal effects for the other categories are presented in Table 5 (Appendix)

Reference categories: not at all important (Sustainability) and find it very hard (household income)

$* * * p$ value $<0.01, * * p$ value $<0.05, * p$ value $<0.10$

$0.007), 0.037$ (0.008), and 0.021 (0.007) for the perceived lack of financial, administrative, and informational support, respectively ( $p$ values $<0.01$ ). Regarding the willingness to take risks, the marginal effect is 0.021 (standard error: $0.012 ; p$ value $<0.10$ ), and for income, bankruptcy and personal failure, the marginal effects are $-0.006(0.009$; $p$ value $>0.10), 0.003(0.009 ; p$ value $>0.10)$, and 0.017 (0.008; $p$ value $<0.05)$, respectively. In other words, when we use sustainability as a continuous variable, we confirm our main conclusions. Namely, Hypotheses 1, 2, and 3 are again supported. Furthermore, Hypothesis 5 is not supported, while Hypothesis 6 is. Additionally, Hypothesis 4 is supported.

Second, we split the sample into nascent entrepreneurs and owner-managers of young businesses. For the sample of nascent entrepreneurs (sample size of 1756), the conclusions are qualitatively similar, except for the risk of personal failure ( $p$ value $>0.10$ ). For the sample of ownermanagers of young businesses (sample size of 1349), the same results are also found, except for financial barriers ( $p$ value $>0.10$ ).

Third, we analyse the results for three geographical regions: (1) Western Europe (including Scandinavia); (2) non-Western Europe (Mediterranean countries, Central Eastern and Southern Eastern countries, and the Baltic States); and (3) the USA. The numbers of observations are 1050, 1673, and 382 for Western Europe, non-Western Europe, and the USA, respectively. There are some regional differences. Namely, Hypothesis 1 is not supported for the three regions (more detailed analyses reveal 
Table 4 Ordered logit and binary logit regressions with perceived risk as the dependent variable: average marginal effects are shown

\begin{tabular}{|c|c|c|c|c|}
\hline & $\begin{array}{l}\text { (1) } \\
\text { Willingness to take } \\
\text { risks (H4) }\end{array}$ & $\begin{array}{l}\text { (2) } \\
\text { Perceived financial risk: } \\
\text { income (H5) }\end{array}$ & $\begin{array}{l}\text { (3) } \\
\text { Perceived financial risk: } \\
\text { bankruptcy (H5) }\end{array}$ & $\begin{array}{l}\text { (4) } \\
\text { Perceived non-financial risk: } \\
\text { personal failure (H6) }\end{array}$ \\
\hline Predicted probability & 0.287 & 0.443 & 0.402 & 0.202 \\
\hline Sustainability (not very important) & $\begin{array}{l}-0.050 \\
(0.035)\end{array}$ & $\begin{array}{l}0.042 \\
(0.031)\end{array}$ & $\begin{array}{l}0.000 \\
(0.030)\end{array}$ & $\begin{array}{l}0.009 \\
(0.023)\end{array}$ \\
\hline Sustainability (fairly important) & $\begin{array}{l}-0.044 \\
(0.039)\end{array}$ & $\begin{array}{l}0.014 \\
(0.033)\end{array}$ & $\begin{array}{l}0.020 \\
(0.031)\end{array}$ & $\begin{array}{l}0.014 \\
(0.019)\end{array}$ \\
\hline Sustainability (very important) & $\begin{array}{l}0.047 \\
(0.045)\end{array}$ & $\begin{array}{l}0.003 \\
(0.027)\end{array}$ & $\begin{array}{l}0.006 \\
(0.031)\end{array}$ & $\begin{array}{l}0.048 * \\
(0.025)\end{array}$ \\
\hline \multicolumn{5}{|l|}{ Control variables } \\
\hline Male & $\begin{array}{l}0.090 * * * \\
(0.022)\end{array}$ & $\begin{array}{l}-0.039 * \\
(0.021)\end{array}$ & $\begin{array}{l}0.037 * * \\
(0.015)\end{array}$ & $\begin{array}{l}-0.035^{* * *} \\
(0.013)\end{array}$ \\
\hline Age & $\begin{array}{l}-0.003 * * * \\
(0.001)\end{array}$ & $\begin{array}{l}-0.003 * * * \\
(0.001)\end{array}$ & $\begin{array}{l}-0.003 * * * \\
(0.000)\end{array}$ & $\begin{array}{l}-0.000 \\
(0.001)\end{array}$ \\
\hline Education & $\begin{array}{l}0.006^{*} \\
(0.004)\end{array}$ & $\begin{array}{l}0.007 * * \\
(0.003)\end{array}$ & $\begin{array}{l}-0.008^{* * *} \\
(0.003)\end{array}$ & $\begin{array}{l}0.001 \\
(0.002)\end{array}$ \\
\hline HH income (find it difficult) & $\begin{array}{l}-0.053 \\
(0.046)\end{array}$ & $\begin{array}{l}0.056 * * \\
(0.026)\end{array}$ & $\begin{array}{l}-0.007 \\
(0.023)\end{array}$ & $\begin{array}{l}0.063 * * \\
(0.026)\end{array}$ \\
\hline HH income (get by) & $\begin{array}{l}-0.093 * * \\
(0.040)\end{array}$ & $\begin{array}{l}-0.001 \\
(0.031)\end{array}$ & $\begin{array}{l}-0.017 \\
(0.029)\end{array}$ & $\begin{array}{l}0.077 * * * \\
(0.023)\end{array}$ \\
\hline HH income (live comfortably) & $\begin{array}{l}-0.001 \\
(0.048)\end{array}$ & $\begin{array}{l}-0.028 \\
(0.043)\end{array}$ & $\begin{array}{l}-0.029 \\
(0.028)\end{array}$ & $\begin{array}{l}0.098 * * * \\
(0.024)\end{array}$ \\
\hline Young versus nascent & $\begin{array}{l}-0.009 \\
(0.022)\end{array}$ & $\begin{array}{l}0.038 * * \\
(0.019)\end{array}$ & $\begin{array}{l}0.018 \\
(0.018)\end{array}$ & $\begin{array}{l}-0.071 * * * \\
(0.015)\end{array}$ \\
\hline 2012 versus 2009 & N.a. & $\begin{array}{l}-0.069 * * * \\
(0.019)\end{array}$ & $\begin{array}{l}-0.060 * * * \\
(0.020)\end{array}$ & $\begin{array}{l}-0.040 * * \\
(0.016)\end{array}$ \\
\hline Observations & 1234 & 3105 & 3105 & 3105 \\
\hline
\end{tabular}

Standard errors (clustered on country) in parentheses. Country dummies are included, but corresponding marginal effects are not shown here. Ordered logit regression was performed in column 1. Marginal effects are shown for the highest category of the dependent variable "willingness to take risks" (strongly agree-value 4), and marginal effects for the other categories of this variable are presented in Table 6 (Appendix). Information is available for 2009 only for "willingness to take risks". Binary logit regressions were performed in columns 2, 3, and 4

Reference categories: not at all important (sustainability) and find it very hard (household income)

$* * * p$ value $<0.01, * * p$ value $<0.05, * p$ value $<0.10$

specific countries in which Hypothesis 1 is supported). Hypothesis 2 is supported for non-Western Europe and the USA, and Hypothesis 3 is supported for Western Europe. Hypothesis 4 is supported for non-Western Europe. Finally, Hypotheses 5 and 6 cannot be supported for any of the regions (support is again found for specific countries).

\section{Discussion and Conclusion}

Whereas entrepreneurship is widely acknowledged for bringing about growth and conferring economic wealth to society (Carree and Thurik 2010), sustainable entrepreneurship is assumed to play the same role in creating societal wealth during times when pressing social and ecological needs are abundant. Despite the growing popularity of sustainable entrepreneurship in academic circles, a thorough investigation of the complexities that sustainable entrepreneurs experience when establishing a business is still needed (Cohen and Winn 2007). The present paper responds to this call.

We start with the argumentation that sustainable entrepreneurs, characterized by a simultaneous pursuit of private and collective gains, face more challenges during the startup process than regular entrepreneurs. We hypothesize that sustainable entrepreneurs operating under circumstances of market imperfections and an unfavourable institutional context with broad knowledge base requirements, perceive 
more institutional barriers and face different types of risks when establishing a business than regular entrepreneurs. Based on two waves of the Flash Eurobarometer survey on entrepreneurship (2009 and 2012)—which contains information on start-up motivations, entrepreneurial barriers, and risk for approximately 3000 (prospective) business owners across 33 countries-our analyses reveal that sustainable entrepreneurs are more negative with respect to the start-up environment in terms of financial and, mainly, non-financial barriers. In addition, we find that sustainable entrepreneurs are more likely to fear personal failure than regular entrepreneurs. In terms of the willingness to take risks, we do not find significant differences between sustainable and regular entrepreneurs, and the two groups do not significantly differ in terms of the financial risks that they perceive.

The present paper is one of the first attempts to uncover different risk attitudes within the two examined groups of entrepreneurs. We find that sustainable and regular entrepreneurs do not significantly differ with respect to their willingness to take risks. However, when we take a broader perspective on the issue of risk, our findings support the idea that sustainable entrepreneurs fear different types of risk when they start a business compared with regular entrepreneurs. Namely, we find evidence that sustainable entrepreneurs fear personal failure to a greater degree than regular entrepreneurs. Sustainable entrepreneurs must cope with more varied and more complex stakeholder relations while challenging rules, norms, and legislation, which puts their reputation and credibility at stake. Future research could determine whether a coping mechanism is at play for the financial risks that sustainable and regular entrepreneurs similarly fear according to the present results. Namely, sustainable entrepreneurs may be motivated to overcome the challenges that they expect to experience during the start-up process, which leads to a lower fear of financial risks. In this respect, the role of other-regarding behaviour and collective interests as opposed to rational self-interest would be an interesting avenue for investigation.

The present study makes some important contributions to our understanding of sustainable entrepreneurs and especially perceptions of the start-up process. Our findings engender to implications for the support structure, education set-ups and (future) research. By investigating risks and barriers perceived by sustainable entrepreneurs relative to the perceptions of regular entrepreneurs, our study suggests that sustainable entrepreneurs perceive a stronger lack of institutional support than regular entrepreneurs. This finding is of importance for those who want to promote sustainable entrepreneurship, such as governments and private capital providers. The start-up environment has to be enhanced, and specific support programmes for starting sustainable entrepreneurs seem warranted. Dedicated support structures, such as sustainable incubators and investment funds for sustainable start-up, should be further stimulated. In addition, providers of subsidies could reconsider the related administrative burdens by facilitating start-ups in their application process. By exploring different types of risk, we draw attention to the importance of the risk of personal failure (while financial risk is more commonly investigated in the entrepreneurship literature). Clearly, addressing the risk of personal failure requires a different support approach, particularly concerning training entrepreneurial skills, such as networking skills, or developing and maintaining relationships with stakeholders. In addition, dedicated training programmes for starting sustainable entrepreneurs may help create awareness for the specificities and additional challenges associated with environmental and social issues. From the perspective of (future) research, our results have implications for our understanding of how different types of entrepreneurs proceed in the entrepreneurial process (Van der Zwan et al. 2012, 2013). Earlier research shows that social entrepreneurs are less likely to be active in the more mature stages of the entrepreneurial process (Bacq et al. 2013). There is also evidence that perceived barriers may hinder entrepreneurs in becoming more involved in the entrepreneurial process (Van der Zwan et al. 2013; Grilo and Thurik 2008; Orser et al. 2000). While previous research has focused on the relationship between perceived barriers and entrepreneurial intentions (Shinnar et al. 2012; Kuckertz and Wagner 2010), follow-up research could focus on how perceptions at start-up affect the experiences of sustainable entrepreneurs during the process of growing their business, including different performance measures.

Our study is not without limitations. The first limitation concerns the measurement of our variable of interest-sustainable entrepreneurship. For social entrepreneurship, a single-item measure that can be used in cross-country research has only recently been constructed (Lepoutre et al. 2013). A validated measure of sustainable entrepreneurship at the individual level has, nonetheless, not been proposed in earlier research (Kuckertz and Wagner 2010). Our measure was added to the questionnaire of the Flash Eurobarometer survey on basis of our feedback on questionnaires from earlier years.

Another limitation of our dataset is that we cannot distinguish between social and environmental entrepreneurship. The respondents revealed the extent to which "addressing an unmet social or ecological need" played a role at firm inception, making it impossible to assess social 
and environmental motivation separately. This is unfortunate because it seems intuitive that more environmentally oriented sustainable entrepreneurs perceive barriers differently from more socially oriented entrepreneurs. Whether this is indeed the case is a subject for future research.

Finally, our conception of sustainable entrepreneurship is at the level of a single individual, namely the (prospective) business owner. Akin to the conception of entrepreneurship (Parker 2009), our conception herewith ignores team starts involving multiple founders. However, emerging empirical evidence indicates that entrepreneurial teams are responsible for many start-ups (Harper 2008). Each of the team members will have their individual perspectives, cognitions, and motives at inception; however, it is the collective perspective and drive at team level that directs the start-up (West 2007). Thus, a discrepancy may exist between our conception of sustainable entrepreneurship measured at the individual level (i.e. single business owner motivation at start-up) and the actual conception that needs to address the firm level (i.e. the collective motivation that guides the sustainable signature of the venture). This is not captured by our survey data.

We provide a few other future research opportunities. Research could focus on the actual outcomes of sustainable (nascent) entrepreneurial activities and the degree to which the goals of the sustainable entrepreneur in terms of social value creation have been fulfilled. Another potential avenue would be to consider the diversity of sustainable ventures. The distinction between sustainable and regular businesses could be characterized as a continuum with different dimensions. For example, sustainable enterprises may differ in the degree to which social and environmental goals are set, as well as the degree to which their level of innovation and their drive to appropriate value are created. In the present paper, we address the diversity among entrepreneurs in terms of the importance of addressing unmet environmental and social needs at start-up by using four ordinal categories. More fine-grained typologies considering the pursuit of private economic gains in addition to the drive to cater to the needs of others would be of interest here. Another possibility for future research would be to inspect country differences in detail. While our main analysis has the advantage of using a large sample, one of our additional analyses highlighted some differences across geographical regions, for example, in terms of the willingness to take risks. A clear overview of differences across countries, as well as an explanation behind these differences, may prove helpful in offering a better understanding of sustainable entrepreneurship.

As a final remark, we would like to stress that understanding the complexities in terms of barriers and risks that sustainable entrepreneurs face and the role of the institutional start-up climate, which is the aim of the present paper, is highly relevant against the background of an increased interest in the role of entrepreneurs for the diffusion of inventions and their contribution to a more sustainable society, as reflected in influential reports such as The Millennium Declaration of the United Nations Development Program (2000) ${ }^{7}$, Europe 2020 (European Commission 2010), and, more recently, the Paris Agreement COP $21^{8}$. The present paper is an attempt to contribute to this understanding.

Open Access This article is distributed under the terms of the Creative Commons Attribution 4.0 International License (http://crea tivecommons.org/licenses/by/4.0/), which permits unrestricted use, distribution, and reproduction in any medium, provided you give appropriate credit to the original author(s) and the source, provide a link to the Creative Commons license, and indicate if changes were made.

\section{Appendix}

See Tables 5, 6, 7, and 8 .

\footnotetext{
7 See http://www.un.org/millenniumgoals (February 22, 2017).

${ }^{8}$ See https://ec.europa.eu/clima/policies/international/negotiations/ paris_en (February 22, 2017).
} 
Table 5 Ordered logit regressions with perceived barriers as the dependent variable: average marginal effects (first three categories)

\begin{tabular}{|c|c|c|c|c|c|c|c|c|c|}
\hline & $\begin{array}{l}\text { Perceived } \\
\text { financial } \\
\text { barrier } \\
\\
\text { Totally } \\
\text { disagree } \\
\text { (value 1) }\end{array}$ & $\begin{array}{l}\text { Perceived } \\
\text { financial } \\
\text { barrier } \\
\text { Tend to } \\
\text { disagree } \\
\text { (value 2) }\end{array}$ & $\begin{array}{l}\text { Perceived } \\
\text { financial } \\
\text { barrier } \\
\text { Tend to } \\
\text { agree } \\
\text { (value 3) }\end{array}$ & $\begin{array}{l}\text { Perceived } \\
\text { non- } \\
\text { financial } \\
\text { barrier: } \\
\text { Administr. } \\
\text { Totally } \\
\text { disagree } \\
\text { (value 1) }\end{array}$ & $\begin{array}{l}\text { Perceived } \\
\text { non- } \\
\text { financial } \\
\text { barrier: } \\
\text { Administr. } \\
\text { Tend to } \\
\text { disagree } \\
\text { (value 2) }\end{array}$ & $\begin{array}{l}\text { Perceived } \\
\text { non- } \\
\text { financial } \\
\text { barrier: } \\
\text { Administr. } \\
\text { Tend to } \\
\text { agree (value } \\
\text { 3) }\end{array}$ & $\begin{array}{l}\text { Perceived } \\
\text { non- } \\
\text { financial } \\
\text { barrier: } \\
\text { Start-up info } \\
\text { Totally } \\
\text { disagree } \\
\text { (value 1) }\end{array}$ & $\begin{array}{l}\text { Perceived } \\
\text { non- } \\
\text { financial } \\
\text { barrier: } \\
\text { Start-up info } \\
\text { Tend to } \\
\text { disagree } \\
\text { (value 2) }\end{array}$ & $\begin{array}{l}\text { Perceived } \\
\text { non- } \\
\text { financial } \\
\text { barrier: } \\
\text { Start-up info } \\
\text { Tend to } \\
\text { agree (value } \\
\text { 3) }\end{array}$ \\
\hline $\begin{array}{l}\text { Predicted } \\
\text { probability }\end{array}$ & 0.053 & 0.132 & 0.377 & 0.113 & 0.193 & 0.338 & 0.217 & 0.294 & 0.264 \\
\hline $\begin{array}{l}\text { Sustainability } \\
\text { (not very } \\
\text { important) }\end{array}$ & $\begin{array}{l}0.004 \\
(0.006)\end{array}$ & $\begin{array}{l}0.007 \\
(0.011)\end{array}$ & $\begin{array}{l}0.006 \\
(0.008)\end{array}$ & $\begin{array}{l}-0.021 \\
(0.019)\end{array}$ & $\begin{array}{l}-0.018 \\
(0.015)\end{array}$ & $\begin{array}{l}0.003 \\
(0.003)\end{array}$ & $\begin{array}{l}-0.005 \\
(0.020)\end{array}$ & $\begin{array}{l}-0.002 \\
(0.006)\end{array}$ & $\begin{array}{l}0.002 \\
(0.009)\end{array}$ \\
\hline $\begin{array}{l}\text { Sustainability } \\
\text { (fairly } \\
\text { important) }\end{array}$ & $\begin{array}{l}-0.000 \\
(0.005)\end{array}$ & $\begin{array}{l}-0.000 \\
(0.010)\end{array}$ & $\begin{array}{l}-0.000 \\
(0.008)\end{array}$ & $\begin{array}{l}-0.039^{* * *} \\
(0.015)\end{array}$ & $\begin{array}{l}-0.037 * * * \\
(0.012)\end{array}$ & $\begin{array}{l}0.002 \\
(0.003)\end{array}$ & $\begin{array}{l}-0.043^{* *} \\
(0.022)\end{array}$ & $\begin{array}{l}-0.016^{* * *} \\
(0.007)\end{array}$ & $\begin{array}{l}0.019 * * \\
(0.010)\end{array}$ \\
\hline $\begin{array}{l}\text { Sustainability } \\
\text { (very } \\
\text { important) }\end{array}$ & $\begin{array}{l}-0.010^{* *} \\
(0.005)\end{array}$ & $\begin{array}{l}-0.020 * * \\
(0.009)\end{array}$ & $\begin{array}{l}-0.020^{* *} \\
(0.009)\end{array}$ & $\begin{array}{l}-0.054 * * * \\
(0.017)\end{array}$ & $\begin{array}{l}-0.054^{* * *} \\
(0.013)\end{array}$ & $\begin{array}{l}-0.003 \\
(0.003)\end{array}$ & $\begin{array}{l}-0.055^{* * *} \\
(0.023)\end{array}$ & $\begin{array}{l}-0.022^{* * *} \\
(0.008)\end{array}$ & $\begin{array}{l}0.024 * * \\
(0.010)\end{array}$ \\
\hline \multicolumn{10}{|c|}{ Control variables } \\
\hline Male & $\begin{array}{l}0.000 \\
(0.003)\end{array}$ & $\begin{array}{l}0.001 \\
(0.007)\end{array}$ & $\begin{array}{l}0.001 \\
(0.006)\end{array}$ & $\begin{array}{l}-0.005 \\
(0.008)\end{array}$ & $\begin{array}{l}-0.005 \\
(0.008)\end{array}$ & $\begin{array}{l}-0.001 \\
(0.001)\end{array}$ & $\begin{array}{l}0.015 \\
(0.009)\end{array}$ & $\begin{array}{l}0.006 \\
(0.004)\end{array}$ & $\begin{array}{l}-0.006 \\
(0.004)\end{array}$ \\
\hline Age & $\begin{array}{l}-0.000 \\
(0.000)\end{array}$ & $\begin{array}{l}-0.000 \\
(0.000)\end{array}$ & $\begin{array}{l}-0.000 \\
(0.000)\end{array}$ & $\begin{array}{l}-0.001 * * * \\
(0.000)\end{array}$ & $\begin{array}{l}-0.001^{* * *} \\
(0.000)\end{array}$ & $\begin{array}{l}-0.000 * * * \\
(0.000)\end{array}$ & $\begin{array}{l}0.000 \\
(0.000)\end{array}$ & $\begin{array}{l}0.000 \\
(0.000)\end{array}$ & $\begin{array}{l}-0.000 \\
(0.000)\end{array}$ \\
\hline Education & $\begin{array}{l}0.001 * \\
(0.001)\end{array}$ & $\begin{array}{l}0.002 * \\
(0.001)\end{array}$ & $\begin{array}{l}0.002 * * \\
(0.001)\end{array}$ & $\begin{array}{l}0.003 * * * \\
(0.001)\end{array}$ & $\begin{array}{l}0.003 * * * \\
(0.001)\end{array}$ & $\begin{array}{l}0.000 * * * \\
(0.000)\end{array}$ & $\begin{array}{l}0.005 * * * \\
(0.002)\end{array}$ & $\begin{array}{l}0.002 * * \\
(0.001)\end{array}$ & $\begin{array}{l}-0.002 * * \\
(0.001)\end{array}$ \\
\hline $\begin{array}{l}\text { HH income } \\
\text { (find it } \\
\text { difficult) }\end{array}$ & $\begin{array}{l}-0.003 \\
(0.006)\end{array}$ & $\begin{array}{l}-0.008 \\
(0.014)\end{array}$ & $\begin{array}{l}-0.013 \\
(0.024)\end{array}$ & $\begin{array}{l}0.015 \\
(0.011)\end{array}$ & $\begin{array}{l}0.018 \\
(0.016)\end{array}$ & $\begin{array}{l}0.008 \\
(0.008)\end{array}$ & $\begin{array}{l}0.005 \\
(0.031)\end{array}$ & $\begin{array}{l}0.003 \\
(0.017)\end{array}$ & $\begin{array}{l}-0.002 \\
(0.012)\end{array}$ \\
\hline $\begin{array}{l}\text { HH income } \\
\text { (get by) }\end{array}$ & $\begin{array}{l}0.015 * * * \\
(0.006)\end{array}$ & $\begin{array}{l}0.033 * * * \\
(0.013)\end{array}$ & $\begin{array}{l}0.041 * * \\
(0.019)\end{array}$ & $\begin{array}{l}0.034 * * * \\
(0.013)\end{array}$ & $\begin{array}{l}0.040 * * \\
(0.017)\end{array}$ & $\begin{array}{l}0.012 \\
(0.008)\end{array}$ & $\begin{array}{l}0.022 \\
(0.028)\end{array}$ & $\begin{array}{l}0.011 \\
(0.015)\end{array}$ & $\begin{array}{l}-0.009 \\
(0.010)\end{array}$ \\
\hline $\begin{array}{l}\mathrm{HH} \text { income } \\
\text { (live } \\
\text { comfortably) }\end{array}$ & $\begin{array}{l}0.037 * * * \\
(0.008)\end{array}$ & $\begin{array}{l}0.073 * * * \\
(0.015)\end{array}$ & $\begin{array}{l}0.067 * * * \\
(0.019)\end{array}$ & $\begin{array}{l}0.040 * * * \\
(0.013)\end{array}$ & $\begin{array}{l}0.046 * * * \\
(0.018)\end{array}$ & $\begin{array}{l}0.013 \\
(0.008)\end{array}$ & $\begin{array}{l}0.043 \\
(0.030)\end{array}$ & $\begin{array}{l}0.019 \\
(0.015)\end{array}$ & $\begin{array}{l}-0.018 \\
(0.011)\end{array}$ \\
\hline $\begin{array}{l}\text { Young versus } \\
\text { nascent }\end{array}$ & $\begin{array}{l}0.000 \\
(0.003)\end{array}$ & $\begin{array}{l}0.001 \\
(0.005)\end{array}$ & $\begin{array}{l}0.001 \\
(0.005)\end{array}$ & $\begin{array}{l}0.020 * * * \\
(0.007)\end{array}$ & $\begin{array}{l}0.021 * * * \\
(0.007)\end{array}$ & $\begin{array}{l}0.003 * * * \\
(0.001)\end{array}$ & $\begin{array}{l}0.008 \\
(0.010)\end{array}$ & $\begin{array}{l}0.004 \\
(0.004)\end{array}$ & $\begin{array}{l}-0.003 \\
(0.004)\end{array}$ \\
\hline $\begin{array}{l}2012 \text { versus } \\
2009\end{array}$ & $\begin{array}{l}-0.018 * * \\
(0.009)\end{array}$ & $\begin{array}{l}-0.033 * * \\
(0.016)\end{array}$ & $\begin{array}{l}-0.030 * * \\
(0.015)\end{array}$ & $\begin{array}{l}-0.013 * \\
(0.008)\end{array}$ & $\begin{array}{l}-0.014^{*} \\
(0.008)\end{array}$ & $\begin{array}{l}-0.002 \\
(0.001)\end{array}$ & $\begin{array}{l}0.010 \\
(0.012)\end{array}$ & $\begin{array}{l}0.004 \\
(0.005)\end{array}$ & $\begin{array}{l}-0.004 \\
(0.005)\end{array}$ \\
\hline Observations & 3105 & 3105 & 3105 & 3105 & 3105 & 3105 & 3105 & 3105 & 3105 \\
\hline
\end{tabular}

Standard errors (clustered on country) in parentheses. Country dummies are included, but corresponding marginal effects are not shown here. Marginal effects are shown for the lowest categories of the dependent variables. Marginal effects for the highest category are presented in Table 3. Reference categories: not at all important (sustainability) and find it very hard (household income)

$* * * p$ value $<0.01, * * p$ value $<0.05, * p$ value $<0.10$

Table 6 Ordered logit regressions with perceived risk as the dependent variable: average marginal effects for the first three categories are shown

\begin{tabular}{|c|c|c|c|}
\hline & $\begin{array}{l}\text { (1) } \\
\text { Willingness to take risks } \\
\text { Strongly disagree (value 1) }\end{array}$ & $\begin{array}{l}\text { W) } \\
\text { Willingness to take risks } \\
\text { Disagree (value 2) }\end{array}$ & $\begin{array}{l}\text { (3) } \\
\text { Willingness to take risks } \\
\text { Agree (value 3) }\end{array}$ \\
\hline Predicted probability & 0.030 & 0.165 & 0.519 \\
\hline Sustainability (not very important) & $\begin{array}{l}0.008 \\
(0.005)\end{array}$ & $\begin{array}{l}0.033 \\
(0.022)\end{array}$ & $\begin{array}{l}0.009 \\
(0.009)\end{array}$ \\
\hline Sustainability (fairly important) & $\begin{array}{l}0.007 \\
(0.006)\end{array}$ & $\begin{array}{l}0.029 \\
(0.024)\end{array}$ & $\begin{array}{l}0.009 \\
(0.009)\end{array}$ \\
\hline
\end{tabular}


Table 6 continued

\begin{tabular}{|c|c|c|c|}
\hline & $\begin{array}{l}\text { (1) } \\
\text { Willingness to take risks } \\
\text { Strongly disagree (value } 1 \text { ) }\end{array}$ & $\begin{array}{l}\text { (2) } \\
\text { Willingness to take risks } \\
\text { Disagree (value 2) }\end{array}$ & $\begin{array}{l}\text { (3) } \\
\text { Willingness to take risks } \\
\text { Agree (value 3) }\end{array}$ \\
\hline Sustainability (very important) & $\begin{array}{l}-0.006 \\
(0.006)\end{array}$ & $\begin{array}{l}-0.025 \\
(0.025)\end{array}$ & $\begin{array}{l}-0.017 \\
(0.015)\end{array}$ \\
\hline \multicolumn{4}{|l|}{ Control variables } \\
\hline Male & $\begin{array}{l}-0.014 * * * \\
(0.004)\end{array}$ & $\begin{array}{l}-0.057 * * * \\
(0.014)\end{array}$ & $\begin{array}{l}-0.020^{* * *} \\
(0.005)\end{array}$ \\
\hline Age & $\begin{array}{l}0.001 * * * \\
(0.000)\end{array}$ & $\begin{array}{l}0.002 * * * \\
(0.001)\end{array}$ & $\begin{array}{l}0.001 * * * \\
(0.000)\end{array}$ \\
\hline Education & $\begin{array}{l}-0.001 \\
(0.001)\end{array}$ & $\begin{array}{l}-0.004 * \\
(0.002)\end{array}$ & $\begin{array}{l}-0.001 \\
(0.001)\end{array}$ \\
\hline $\mathrm{HH}$ income (find it difficult) & $\begin{array}{l}0.007 \\
(0.006)\end{array}$ & $\begin{array}{l}0.030 \\
(0.024)\end{array}$ & $\begin{array}{l}0.017 \\
(0.016)\end{array}$ \\
\hline HH income (get by) & $\begin{array}{l}0.013 * * * \\
(0.005)\end{array}$ & $\begin{array}{l}0.057 * * * \\
(0.022)\end{array}$ & $\begin{array}{l}0.022 \\
(0.015)\end{array}$ \\
\hline $\mathrm{HH}$ income (live comfortably) & $\begin{array}{l}0.001 \\
(0.005)\end{array}$ & $\begin{array}{l}0.001 \\
(0.024)\end{array}$ & $\begin{array}{l}0.000 \\
(0.019)\end{array}$ \\
\hline Young versus nascent & $\begin{array}{l}0.001 \\
(0.003)\end{array}$ & $\begin{array}{l}0.005 \\
(0.014)\end{array}$ & $\begin{array}{l}0.002 \\
(0.005)\end{array}$ \\
\hline Observations & 1234 & 1234 & 1234 \\
\hline
\end{tabular}

Standard errors (clustered on country) in parentheses. Country dummies are included, but corresponding marginal effects are not shown here. Marginal effects are shown for the lowest three categories of the risk variable. Marginal effects for the highest category of this variable are presented in Table 4. Information is available for 2009 only for "willingness to take risks"

Reference categories: not at all important (sustainability) and find it very hard (household income)

$* * * p$ value $<0.01, * * p$ value $<0.05, * p$ value $<0.10$

Table 7 Ordered logit regressions with perceived barriers as the dependent variable: average marginal effects are shown. Reference category for sustainability: "fairly important"

\begin{tabular}{|c|c|c|c|}
\hline & $\begin{array}{l}\text { (1) } \\
\text { Perceived financial } \\
\text { barrier }\end{array}$ & $\begin{array}{l}\text { (2) } \\
\text { Perceived non-financial barrier: } \\
\text { administrative complexities }\end{array}$ & $\begin{array}{l}\text { (3) } \\
\text { Perceived non-financial barrier: } \\
\text { lack of start-up info }\end{array}$ \\
\hline Predicted probability & 0.439 & 0.356 & 0.225 \\
\hline Sustainability (not at all important) & $\begin{array}{l}-0.001 \\
(0.023)\end{array}$ & $\begin{array}{l}-0.073^{* * *} \\
(0.024)\end{array}$ & $\begin{array}{l}-0.041 * * \\
(0.019)\end{array}$ \\
\hline Sustainability (not very important) & $\begin{array}{l}-0.017 \\
(0.021)\end{array}$ & $\begin{array}{l}-0.037 \\
(0.023)\end{array}$ & $\begin{array}{l}-0.036^{* * *} \\
(0.014)\end{array}$ \\
\hline Sustainability (very important) & $\begin{array}{l}0.050 * * * \\
(0.014)\end{array}$ & $\begin{array}{l}0.038 * * \\
(0.019)\end{array}$ & $\begin{array}{l}0.013 \\
(0.019)\end{array}$ \\
\hline Observations & 3105 & 3105 & 3105 \\
\hline
\end{tabular}

Standard errors (clustered on country) in parentheses. Results for control variables (including country dummies) as in Table 3. Marginal effects are shown for the highest category of the dependent variables (totally agree-value 4)

Reference category: fairly important (sustainability)

$* * * p$ value $<0.01, * * p$ value $<0.05, * p$ value $<0.10$ 
Table 8 Ordered logit and binary logit regressions with perceived risk as the dependent variable: average marginal effects are shown. Reference category for sustainability: "fairly important"

\begin{tabular}{|c|c|c|c|c|}
\hline & $\begin{array}{l}\text { (1) } \\
\text { Willingness to take } \\
\text { risks }\end{array}$ & $\begin{array}{l}\text { (2) } \\
\text { Perceived financial risk: } \\
\text { income }\end{array}$ & $\begin{array}{l}\text { (3) } \\
\text { Perceived financial risk: } \\
\text { bankruptcy }\end{array}$ & $\begin{array}{l}\text { (4) } \\
\text { Perceived non-financial risk: } \\
\text { personal failure }\end{array}$ \\
\hline Predicted probability & 0.287 & 0.443 & 0.402 & 0.202 \\
\hline \multirow{2}{*}{$\begin{array}{l}\text { Sustainability (not at all } \\
\text { important) }\end{array}$} & 0.044 & -0.014 & -0.020 & -0.014 \\
\hline & $(0.039)$ & $(0.033)$ & $(0.031)$ & $(0.019)$ \\
\hline \multirow{2}{*}{$\begin{array}{l}\text { Sustainability (not very } \\
\text { important) }\end{array}$} & -0.005 & 0.028 & -0.020 & -0.005 \\
\hline & $(0.021)$ & $(0.024)$ & $(0.025)$ & $(0.019)$ \\
\hline \multirow{2}{*}{$\begin{array}{l}\text { Sustainability (very } \\
\text { important) }\end{array}$} & $0.092 * * *$ & -0.011 & -0.015 & $0.034 * *$ \\
\hline & $(0.029)$ & $(0.025)$ & $(0.024)$ & $(0.017)$ \\
\hline Observations & 1234 & 3105 & 3105 & 3105 \\
\hline
\end{tabular}

Standard errors (clustered on country) in parentheses. Results for control variables (including country dummies) as in Table 4. Ordered logit regression was performed in column 1. Marginal effects are shown for the highest category of the dependent variable "willingness to take risks" (strongly agree-value 4). Information is available for 2009 only for "willingness to take risks". Binary logit regressions were performed in columns 2,3 , and 4

Reference category: fairly important (sustainability)

$* * * p$ value $<0.01, * * p$ value $<0.05, * p$ value $<0.10$

\section{References}

Alvord, S. H., Brown, L. D., \& Letts, C. W. (2004). Social entrepreneurship and societal transformation: An exploratory study. The Journal of Applied Behavioral Science, 40(3), 260-282.

Arenius, P., \& Minniti, M. (2005). Perceptual variables and nascent entrepreneurship. Small Business Economics, 24(3), 233-247.

Audretsch, D. B., \& Thurik, A. R. (2001). What is new about the new economy: sources of growth in the managed and entrepreneurial economies. Industrial and Corporate Change, 10(1), 267-315.

Audretsch, D. B., \& Thurik, A. R. (2004). A model of the entrepreneurial economy. International Journal of Entrepreneurship Education, 2(2), 143-166.

Bacq, S., Hartog, C., \& Hoogendoorn, B. (2013). A quantitative comparison of social and commercial entrepreneurship: Toward a more nuanced understanding of social entrepreneurship organizations in context. Journal of Social Entrepreneurship, $4(1), 40-68$.

Bacq, S., Hartog, C., \& Hoogendoorn, B. (2016). Beyond the moral portrayal of social entrepreneurs: an empirical approach to who they are and what drives them. Journal of Business Ethics, 133(4), 703-718.

Battilana, J., Leca, B., \& Boxenbaum, E. (2009). How actors change institutions: towards a theory of institutional entrepreneurship. Academy of Management Annals, 3(1), 65-107.

Birley, S. (1985). The role of networks in the entrepreneurial process. Journal of Business Venturing, 1(1), 107-117.

Block, J., Sandner, P., \& Spiegel, F. (2015). How do risk attitudes differ within the group of entrepreneurs? The role of motivation and procedural utility. Journal of Small Business Management, 53(1), 183-206.

Bonin, H., Constant, A., Tatsiramos, K., \& Zimmermann, K. F. (2009). Native-migrant differences in risk attitudes. Applied Economics Letters, 16(15), 1581-1586.

Bönte, W., \& Piegeler, M. (2013). Gender gap in latent and nascent entrepreneurship: driven by competitiveness. Small Business Economics, 41(4), 961-987.
Bosma, N., Schøtt, T., Terjesen, S., \& Kew, P. (2016). Global Entrepreneurship Monitor. Special Topic Report Social Entrepreneurship.

Brockhaus, R. H. (1980). Risk taking propensity of entrepreneurs. Academy of Management Journal, 23(3), 509-520.

Buchholz, R. A., \& Rosenthal, S. B. (2005). The spirit of entrepreneurship and the qualities of moral decision making. Journal of Business Ethics, 60(3), 307-315.

Burch, S., Andrachuk, M., Carey, D., Frantzeskaki, N., Schroeder, H., Mischkowski, N., et al. (2016). Governing and accelerating transformative entrepreneurship: exploring the potential for small business innovation on urban sustainability transitions. Environmental Sustainability, 22, 26-32.

Carree, M. A., \& Thurik, A. R. (2010). The impact of entrepreneurship on economic growth. In Z. J. Acs \& D. Audretsch (Eds.), Handbook of entrepreneurship research (pp. 557-594). Berlin: Springer.

Castka, P., Balzarova, M. A., Bamber, C. J., \& Sharp, J. M. (2004). How can SMEs effectively implement the CSR agenda? A UK case study perspective. Corporate Social Responsibility and Environmental Management, 11(3), 140-149.

Cohen, B., \& Winn, M. I. (2007). Market imperfections, opportunity and sustainable entrepreneurship. Journal of Business Venturing, 22(1), 29-49.

Cornes, R., \& Sandler, T. (1996). The theory of externalities, public goods, and club goods. Cambrigde: Cambridge University Press.

Dacin, P. A., Dacin, M. T., \& Matear, M. (2010). Social entrepreneurship: Why we don't need a new theory and how we move forward from here. Academy of Management Perspectives, 24(2), 36-56.

Dasgupta, P. (1990). The environment as a commodity. Oxford review of economic policy (pp. 51-67).

Davidsson, P. (2006). Nascent entrepreneurship: empirical studies and developments. Foundations and Trends in Entrepreneurship, $2(1), 1$.

De Marchi, V. (2012). Environmental innovation and R\&D cooperation: Empirical evidence from Spanish manufacturing firms. Research Policy, 41(3), 614-623. 
Dean, T. J., \& McMullen, J. S. (2007). Toward a theory of sustainable entrepreneurship: Reducing environmental degradation through entrepreneurial action. Journal of Business Venturing, 22(1), $50-76$.

DiDomenico, M., Haugh, H., \& Tracey, P. (2010). Social bricolage: Theorizing social value creation in social enterprises. Entrepreneurship Theory and Practice, 34(5), 681-703.

DiMaggio, P. J. (1988). Interest and agency in institutional theory. In L. Zucker (Ed.), Institutional patterns and organizations (pp. 3-22). Cambridge: Ballinger.

Dohmen, T., Falk, A., Huffman, D., Sunde, U., Schupp, J., \& Wagner, G. G. (2011). Individual risk attitudes: Measurement, determinants, and behavioral consequences. Journal of the European Economic Association, 9(3), 522-550.

Dorado, S. (2006). Social entrepreneurial ventures: Different values so different process of creation, no? Journal of Developmental Entrepreneurship, 11(4), 319-343.

Edelman, L., \& Yli-Renko, H. (2010). The impact of environment and entrepreneurial perceptions on venture-creation efforts: bridging the discovery and creation views of entrepreneurship. Entrepreneurship Theory and Practice, 34(5), 833-856.

Elkington, J. (1997). Cannibals with forks. The triple bottom line of 21st century. Canada: New Society Publishers.

Elkington, J., \& Hartigan, P. (2008). The power of unreasonable people. Boston: Harvard Business Press.

European commission (2010). Europe 2020. A strategy for smart, sustainable and inclusive growth. (Accessed February 20, 2017), http://eur-lex.europa.eu/LexUriServ/LexUriServ.do?uri=COM: 2010:2020:FIN:EN:PDF

European commission (2012). Flash eurobarometer 354. Entrepreneurship in the EU and beyond. Report (Accessed February 20, 2017). http://ec.europa.eu/public_opinion/flash/fl_ 354_en.pdf.

Folke, C. (1999). Ecological principles and environmental economic analysis. In J. Van den Bergh (Ed.), Handbook of environmental and resource economics. Cheltenham: Edward Elgar.

Gasse, Y. (1982). Elaborations on the psychology of the entrepreneur. In C. A. Kent. D. L. Sexton. \& K. H. Vesper (Eds.). Encyclopedia of entrepreneurship (pp. 209-223). Englewood Cliffs: Prentice Hall.

Grilo, I., \& Thurik, A. R. (2005). Entrepreneurial engagement levels in the European Union. International Journal of Entrepreneurship Education, 3(2), 143-168.

Grilo, I., \& Thurik, R. (2008). Determinants of entrepreneurial engagement levels in Europe and the US. Industrial and Corporate Change, 17(6), 1113-1145.

Groot, K., \& Pinkse, J. (2015). Sustainable entrepreneurship and corporate political activity: Overcoming market barriers in the clean energy sector. Entrepreneurship Theory and Practice, $39(3), 633-654$.

Hannafey, F. T. (2003). Entrepreneurship and ethics: A literature review. Journal of Business Ethics, 46(2), 99-110.

Hansen, E. G., \& Schaltegger, S. (2013). 100 per cent organic? A sustainable entrepreneurship perspective on the diffusion of organic clothing. Corporate Governance, 13(5), 583-598.

Harper, D. A. (2008). Towards a theory of entrepreneurial teams. Journal of Business Venturing, 23(6), 613-626.

Hartog, J., Ferrer-i-Carbonell, A., \& Jonker, N. (2002). Linking measured risk aversion to individual characteristics. Kyklos, $55(1), 3-26$.

Haugh, H. (2007). Community-led social venture creation. Entrepreneurship Theory and Practice, 31(2), 161-182.

Hockerts, K., \& Wüstenhagen, R. (2010). Greening Goliaths versus emerging Davids-Theorizing about the role of incumbents and new entrants in sustainable entrepreneurship. Journal of Business Venturing, 25(5), 481-492.
Jaeger, D. A., Dohmen, T., Falk, A., Huffman, D., Sunde, U., \& Bonin, H. (2010). Direct evidence on risk attitudes and migration. The Review of Economics and Statistics, 92(3), 684-689.

Jaffe, A. B., Newell, R. G., \& Stavins, R. N. (2005). A tale of two market failures: Technology and environmental policy. Ecological Economics, 54(2), 164-174.

Johnson, P. S., Parker, S. C., \& Wijbenga, F. (2006). Nascent entrepreneurship research: achievements and opportunities. Small Business Economics, 27(1), 1-4.

Jones, T. M., Felps, W., \& Bigley, G. A. (2007). Ethical theory and stakeholder-related decisions: The role of stakeholder culture. Academy of Management Review, 32(1), 137-155.

Kerlin, J. A. (Ed.). (2009). Social enterprise: A global comparison. Medford: Tufts University Press.

Kihlstrom, R. E., \& Laffont, J.-J. (1979). A general equilibrium entrepreneurial theory of firm formation based on risk aversion. Journal of Political Economy, 87(4), 719-748.

Knight, F. H. (1921). Risk, uncertainty and profit. New York: Houghton-Mifflin.

Koellinger, P. D., Minniti, M., \& Schade, Ch. (2007). I think I can, I think I can: Overconfidence and entrepreneurial behavior. Journal of Economic Psychology, 28(4), 502-527.

Koellinger, P. D., Minniti, M., \& Schade, Ch. (2013). Gender differences in entrepreneurial propensity. Oxford Bulletin of Economics and Statistics, 75(2), 213-234.

Kuckertz, A., \& Wagner, M. (2010). The influence of sustainability orientation on entrepreneurial intentions-Investigating the role of business experience. Journal of Business Venturing, 25(5), 524-539.

Leadbeater, C. (1997). The rise of the social entrepreneur. London: Demos.

Leahy, G., \& Villeneuve-Smith, F. (2009). State of social enterprise survey. London: Social Enterprise Coalition.

Lee, L., Wong, P. K., Der Foo, M., \& Leung, A. (2011). Entrepreneurial intentions: The influence of organizational and individual factors. Journal of Business Venturing, 26(1), $124-136$

Leeming, K. (2002). Community businesses-lessons from Liverpool UK. Community Development Journal, 37(3), 260-267.

Lepoutre, J., Justo, R., Terjesen, S., \& Bosma, N. (2013). Designing a global standardized methodology for measuring social entrepreneurship activity: The global entrepreneurship monitor social entrepreneurship study. Small Business Economics, 40(3), 693-714.

Mair, J., \& Martí, I. (2006). Social entrepreneurship research: A source of explanation, prediction, and delight. Journal of World Business, 41(1), 36-44.

Marin, G., Marzucchi, A., \& Zoboli, R. (2015). SMEs and barriers to Eco-innovation in the EU: exploring different firm profiles. Journal of Evolutionary Economics, 25(3), 671-705.

McGrath, R. G., \& MacMillan, I. C. (1992). More like each other than anyone else? A cross-cultural study of entrepreneurial perceptions. Journal of Business Venturing, 7(5), 419-429.

Meek, D. R., Pacheco, D. F., \& York, J. G. (2010). The impact of social norms on entrepreneurial action: Evidence from the environmental entrepreneurship context. Journal of Business Venturing, 25(5), 493-509.

Nicholls, A. (Ed.). (2006). Social entrepreneurship: New models of sustainable social change. Oxford: Oxford University Press.

Nicholls, A. (2009). We do good things, don't we? Blended value accounting in social entrepreneurship. Accounting, Organizations and Society, 34(6-7), 755-769.

Nyssens, M. (Ed.). (2006). Social enterprise: At the crossroads of markets public policies and civil society. London: Routledge, Taylor Francis Group. 
Orser, B. J., Hogarth-Scott, S., \& Riding, A. L. (2000). Performance, firm size, and management problem solving. Journal of Small Business Management, 38(4), 42.

Pacheco, D. F., Dean, T. J., \& Payne, D. S. (2010). Escaping the green prison: Entrepreneurship and the creation of opportunities for sustainable development. Journal of Business Venturing, 25(5), 464-480.

Parker, S. C. (2009). The economics of entrepreneurship. Cambridge: Cambridge University Press.

Purdue, D. (2001). Neighborhood governance: Leadership, trust and social capital. Urban Studies, 38(12), 2211-2224.

Quinn, J. J. (1997). Personal ethics and business ethics: The ethical attitudes of owner/managers of small business. Journal of Business Ethics, 16(2), 119-127.

Rangan, S., Samii, R., \& Van Wassenhove, L. N. (2006). Constructive partnerships: When alliances between private firms and public actors can enable creative strategies. Academy of Management Review, 31(3), 738-751.

Ray, D. M. (1994). The role of risk-taking in Singapore. Journal of Business Venturing, 9(2), 157-177.

Rennings, K. (2000). Redefining innovation-eco-innovation research and the contribution from ecological economics. Ecological Economics, 32(2), 319-332.

Rizos, V., Behrens, A., Kafyeke, T., Hirschnitz-Garbers, M., \& Ioannou, A. (2015). The circular economy: Barriers and opportunities for SMEs. Brussels: CEPS.

Santos, F. M. (2012). A positive theory of social entrepreneurship. Journal of Business Ethics, 111(3), 335-351.

Schaltegger, S., Lüdeke-Freund, F., \& Hansen, E. G. (2016). Business models for sustainability: A co-evolutionary analysis of sustainable entrepreneurship, innovation, and transformation. Organization \& Environment, 29(3), 264-289.

Schaltegger, S., \& Wagner, M. (2011). Sustainable entrepreneurship and sustainability innovation: categories and interactions. Business Strategy and the Environment, 20(4), 222-237.

Shane, S., \& Venkataraman, S. (2000). The promise of entrepreneurship as a field of research. Academy of Management Review, 25(1), 217-226.

Sharir, M., \& Lerner, M. (2006). Gauging the success of social ventures initiated by individual social entrepreneurs. Journal of World Business, 41(1), 6-20.

Shaw, E., \& Carter, S. (2007). Social entrepreneurship: Theoretical antecedents and empirical analysis of entrepreneurial processes and outcomes. Journal of Small Business and Enterprise Development, 14(3), 418-434.

Shepherd, D. A., \& Patzelt, H. (2011). The new field of sustainable entrepreneurship: studying entrepreneurial action linking "what is to be sustained" with "what is to be developed". Entrepreneurship Theory and Practice, 35(1), 137-163.

Shinnar, R. S., Giacomin, O., \& Janssen, F. (2012). Entrepreneurial perceptions and intentions: The role of gender and culture. Entrepreneurship Theory and Practice, 36(3), 465-493.
Thomas, A. S., \& Mueller, S. L. (2000). A case for comparative entrepreneurship: Assessing the relevance of culture. Journal of International Business Studies, 31(2), 287-301.

Thompson, N., Kiefer, K., \& York, J. G. (2011). Distinctions not dichotomies: Exploring social, sustainable, and environmental entrepreneurship. Social and Sustainable Entrepreneurship (Advances in Entrepreneurship, Firm Emergence and Growth, Volume 13) (pp. 201-229). Bingley: Emerald Group Publishing Limited.

Van de Ven, A. H., Sapienza, H. J., \& Villanueva, J. (2007). Entrepreneurial pursuits of self-and collective interests. Strategic Entrepreneurship Journal, 1(3-4), 353-370.

Van der Zwan, P., Verheul, I., \& Thurik, A. R. (2012). The entrepreneurial ladder, gender, and regional development. Small Business Economics, 39(3), 627-643.

Van der Zwan, P., Verheul, I., Thurik, R., \& Grilo, I. (2013). Entrepreneurial progress: Climbing the entrepreneurial ladder in Europe and the United States. Regional Studies, 47(5), 803-825.

Van Stel, A., Carree, M., \& Thurik, R. (2005). The effect of entrepreneurial activity on national economic growth. Small Business Economics, 24(3), 311-321.

Verheul, I., Thurik, R., Grilo, I., \& Van der Zwan, P. (2012). Explaining preferences and actual involvement in self-employment: Gender and the entrepreneurial personality. Journal of Economic Psychology, 33(2), 325-341.

Weber, E. U., \& Milliman, R. A. (1997). Perceived risk attitudes: Relating risk perception to risky choice. Management Science, 43(2), 123-144.

West, G. P. (2007). Collective cognition: When entrepreneurial teams, not individuals, make decisions. Entrepreneurship Theory and Practice, 31(1), 77-102.

World Commission on Environment and Development (WCED). (1987). Our common future. Oxford: Oxford University Press.

$\mathrm{Xu}$, H., \& Ruef, M. (2004). The myth of the risk-tolerant entrepreneur. Strategic Organization, 2(4), 331-355.

York, J. G., \& Lenox, M. J. (2014). Exploring the sociocultural determinants of de novo versus de alio entry in emerging industries. Strategic Management Journal, 35(13), 1930-1951.

York, J. G., O'Neil, I., \& Sarasvathy, S. D. (2016). Exploring environmental entrepreneurship: identity coupling, venture goals, and stakeholder incentives. Journal of Management Studies, 53(5), 695-737.

York, J. G., \& Venkataraman, S. (2010). The entrepreneur-environment nexus: Uncertainty, innovation, and allocation. Journal of Business Venturing, 25(5), 449-463.

Zahra, S. A., Gedajlovic, E., Neubaum, D. O., \& Shulman, J. M. (2009). A typology of social entrepreneurs: Motives, search processes and ethical challenges. Journal of Business Venturing, 24(5), 519-532.

Zahra, S. A., Rawhouser, H. N., Bhawe, N., Neubaum, D. O., \& Hayton, J. C. (2008). Globalization of social entrepreneurship opportunities. Strategic Entrepreneurship Journal, 2(2), 117-131. 